\title{
The effect of perceived morbidity and mortality risk on risk-taking and patience
}

\author{
Mélusine Boon-Falleur ${ }^{1}$, Brigitte Dormont ${ }^{2, a}$, Coralie Chevallier ${ }^{3, a}$ \\ ${ }^{1}$ Institut Jean Nicod, Département d'études cognitives, ENS, PSL, EHESS, 75005 Paris, France \\ ${ }^{2}$ Université Paris Dauphine-PSL, LEDa, CNRS, IRD, Paris, France \\ ${ }^{3}$ Laboratoire de Neurosciences Cognitives, Département d'études cognitives, ENS, PSL, \\ INSERM, Paris, France \\ ${ }^{a}$ Authors contributed equally
}

\begin{abstract}
Beyond immediate health consequences, the COVID-19 pandemic has profoundly affected people's environment. People had to adapt to new circumstances and take into account the risks related to COVID-19 in their everyday decisions. Given the unprecedented circumstances associated with the first wave of the COVID-19 pandemic, we might ask how people adapt to their new environment. In particular, we ask how people form their morbidity and mortality risk perception associated with the virus and whether increased perceived risk affects psychological traits, such as risk-taking and patience. To address these questions, we analyzed data from a large survey conducted during the first wave in France on 5,000 nationally-representative people. We find that people use the public information on COVID-19 deaths in the area where they live to form their perceived morbidity and mortality risk. Using a structural model approach to lift endogeneity concerns, we found that higher perceived morbidity and mortality risk increases risk aversion. We also found that higher perceived morbidity and mortality risk leads to less patience, although this was only observed for high levels of perceived risk.
\end{abstract}

\section{Keywords}

Risk-taking; patience; perceived risk; structural model; COVID-19. 


\section{Introduction}

The COVID-19 pandemic has brought unprecedented disruptions in individuals' lives around the world. In addition to exceptional national policies, from social distancing to lock-downs, people also had to cope with the risk of becoming infected, being sick or even dying from COVID-19. Risk perception is the output of a cognitive assessment of the threat that the virus imposes on one's health. Evidence shows the assessment of risk is influenced by emotional, cognitive, social, and cultural variations both between individuals and between countries (Douglas \& Wildavsky, 1983; Joffe, 2003; Leiserowitz, 2006; G. F. Loewenstein et al., 2001; Slovic, 1987; Slovic et al., 1982; van der Linden, 2015). In addition, evidence shows that people's risk perception is influenced by the information that is available to them, both publicly and privately. For example, people who spend more time on social media perceive higher mortality and morbidity risk associated with COVID-19 (Xiong et al., 2020). The pandemic thus provides a unique opportunity to study how people form their expectations about being infected or suffering from other adverse health consequences, and how this perceived morbidity and mortality risk affects other psychological traits (Safra et al., 2021), such as risk-taking and patience.

Behavioural scientists have argued that both risk and time preferences adapt to the specific circumstances an individual faces (Amir et al., 2018; Mishra, 2014; Mishra \& Lalumière, 2010; Pepper \& Nettle, 2017; Stephens D. W., 1981). For example, people who are exposed to risks of sickness and death need more somatic resources to fight the disease, and are therefore less able to withstand a loss or to delay gains (Pepper \& Nettle, 2013). People who experience close bereavement also have steeper time discounting (Prokosch et al., 2019), and higher extrinsic mortality perception is associated with diminished investment in preventative health (Ciancio et al., 2020; Pepper \& Nettle, 2014a, 2014b). Research has also shown that nonhuman animals who engage in riskier behaviours experience more frequent and intense infections due to the higher energy expenditure and potential for resource loss (Horvath et al., 2016; Marinov et al., 2017). Recent papers suggest that risk-taking and patience are influenced by personal experience, including negative shocks such as natural disasters (Callen, 2015; Cassar et al., 2017; Hanaoka et al., 2018; Page et al., 2014), conflicts or violence trauma (Callen et al., 2014; Kettlewell et al., 2018), financial adversity (Guiso et al., 2018; G. Loewenstein \& Angner, 2003; Malmendier \& Nagel, 2009), and health shocks (Decker \& Schmitz, 2016; Prokosch et al., 2019). Taken 
together, these findings suggest that, by threatening people's health and economic safety, the shock created by the COVID-19 pandemic may transform psychological preferences. To test this hypothesis, we take advantage of the large geographical variability in the prevalence of COVID-19 cases and related deaths in France during the first wave of the pandemic.

This unique dataset allows us to lift a pervasive endogeneity concern in the literature. When trying to understand which factors affect risk-taking and patience, it is indeed difficult to figure out how much perceived morbidity and mortality risk actually reflects preexisting differences in time and risk preferences. For example, someone who is less patient may have poorer health and therefore be more vulnerable to the health risks associated with COVID-19. Conversely, people who are less risk-seeking may avoid behaviours that increase the probability of becoming infected with SARS-CoV-2. Such individuals would report both low risk-taking and low morbidity and mortality perceived risk because they are not exposing themselves to any risk, e.g. by staying at home. In addition to this reverse causality issue, morbidity and mortality risk perception may be correlated to unobserved psychological traits, such as anxiety, that can influence time and risk preferences. If a common factor independently affects morbidity and mortality risk perception and patience (or risk-taking), standard regressions will yield a biased estimate of the relationship between risk perception and patience (or risk-taking). To address these endogeneity concerns, we use a structural model. This econometric method allows us to compute an estimate that is solely based on the fraction of perceived morbidity and mortality risk variability that is correlated to an exogenous variable, named instrumental variable. In the case of the COVID-19 pandemic, our rationale was that public information on COVID-19 morbidity at the local level can be used as an instrumental variable to estimate the impact of perceived morbidity and mortality risk on patience and risk-taking (Phillips \& Hansen, 1990).

This study is also novel in that it explores the effect of an anticipated shock (the expectation of becoming sick or dying from COVID-19 in the future) rather than the effect of a realized shock (e.g., the impact of a natural catastrophe). Any behavioral response to perceived risk would shed light on how people adapt to anticipated future risk. 


\section{Methods}

\section{Ethics informations}

The study design and data collection was conducted according to the ICC - ESOMAR international code for market research, social and opinion studies and data analytics. In addition, data collection, storage and analysis respected applicable data protection laws and all the new rules related to the European GDPR regulations ${ }^{1}$. All participants had to give their informed consent to be surveyed. The data was made publicly available under condition of anonymity. The geographical information included in our study is coarse enough to prevent indirect identification of individual participants.

\section{Sampling plan}

Our data comes from one module of a repeated weekly survey conducted by Data-Covid from April 7th, 2020 to June 9th, 2020 in order to track individuals' reactions and behaviours in France during the pandemic. The data collection corresponds to the 8th wave of this survey. It took place at the beginning of June 2020, a few weeks after the end of the first lockdown imposed by the French government (the first French lockdown took place between March 16th and May 11th, 2020). In line with the needs of our empirical evaluation, the period in which the data were collected coincides with a period in which regional disparities in the prevalence of COVID-19 were important, and in which all citizens were still subjected to the same regulations (such as maximum capacities in bars and restaurants). As a result, two individuals sampled randomly across the French territory experienced similar lifestyle changes, while being exposed to different numbers of COVID-19 cases and deaths. A sample of 5,000 French adult citizens was surveyed. The sampling process was stratified to ensure representativeness in terms of age, sex, socioeconomic status, department of residence and population density of the residence (e.g., urban versus suburban). A summary of participants' personal characteristics can be found in Table 1.

\footnotetext{
${ }^{1}$ The General Data Protection Regulation (GDPR) is a regulation in EU law on data protection and privacy in the European Union (EU) aimed primarily at giving people control over their personal data.
} 
Table 1. Summary statistics.

\begin{tabular}{|l|l|l|l|l|l|l|l|}
\hline Statistic & $\mathbf{N}$ & Mean & St. Dev. & Min & Pctl(25) & Pctl(75) & Max \\
\hline $\begin{array}{l}\text { Gender (female }= \\
\text { 1) }\end{array}$ & 5,000 & 0.55 & 0.50 & 0 & 0 & 1 & 1 \\
\hline Age & 5,000 & 46.72 & 15.10 & 18 & 35 & 60 & 65 \\
\hline Income & 5,000 & 5.60 & 1.46 & 1.00 & 5.00 & 7.00 & 7.00 \\
\hline Health Worker & 5,000 & 0.01 & 0.10 & 0 & 0 & 0 & 1 \\
\hline Working Outside & 5,000 & 0.30 & 0.46 & 0 & 0 & 1 & 1 \\
\hline $\begin{array}{l}\text { Family or Friend } \\
\text { had COVID-19 }\end{array}$ & 5,000 & 0.10 & 0.30 & 0 & 0 & 0 & 1 \\
\hline $\begin{array}{l}\text { Perceived } \\
\text { combined risk }\end{array}$ & 5,000 & 10.64 & 8.94 & 1.00 & 1.00 & 20.00 & 25.00 \\
\hline \% deaths & 5,000 & 0.03 & 0.02 & 0.001 & 0.01 & 0.04 & 0.13 \\
\hline
\end{tabular}

For each participant, we recorded several demographic variables: gender $(1=$ female $)$, age, income per month (from $1=$ less than $500 €$ per month, to $7=$ more than $3,000 €$ per month, with the option to answer "I prefer not say"), whether the individual was a health worker ("health worker"), whether the individual had to work outside during the lockdown ("working outside"), whether a family member of close friend was sick or died as a result of COVID-19 ("family or friend COVID-19"), the individual's perceived combined morbidity and mortality risk ("perceived combined risk", with the option of answering "I don't know"), and the percentage of deaths in the department ("\% deaths").

\section{Design}

Each participant completed the same online survey for a total duration of approximately 25 minutes. The first part of the survey consisted of demographic questions (age, gender, department of residence and socioeconomic status). The second part of the survey included COVID-19 related questions, such as respondents' current work situation (e.g., furloughed, work from home, etc.). The third part of the survey included five questions measuring respondents' risk-taking and five questions measuring their patience. The final part of the survey assessed respondents' perception of their COVID-19 mortality and morbidity risk. In the following paragraphs, we provide details of the different measures used in the survey. 
Measure of perceived morbidity and mortality risk. Our measures of perceived morbidity and mortality risk consisted of the following questions: (1) What is the probability that you become infected with SARS-CoV-2? (2) What is the probability that you become very sick as a result of being infected with SARS-CoV-2? (3) What is the probability that you die as a result of contracting COVID-19? For each question, respondents answered on a scale with six values $1 \%$, $5 \%, 10 \%, 15 \%, 20 \%$ and $25 \%$. For each question, participants also had the possibility to answer "I don't know". We focused our analysis on participants who selected a value for perceived risk for all three questions. We looked at the three measures independently and also created a combined index of risk perception by computing the average of the three risk probabilities. Figure 1(a) shows that there are large departmental disparities in the average level of combined morbidity and mortality risk perception. For example, individuals living in Ile-de-France, the region that encompasses Paris, perceived that they were exposed to increased morbidity and mortality risk compared to individuals in the South-Western part of France.

Looking at the distribution of perceived risk, we notice that it follows a bi-modal distribution, as many individuals report $1 \%$ perceived risk, many people report 25\% risk, and the rest is uniformly distributed in between (see Appendix Figure A1 for the histogram of risk perception). We therefore combined these categories to create a categorical variable with three values: low perceived risk (1\%), medium perceived risk (between $1 \%$ and $25 \%$ ), and high perceived risk $(25 \%)$.

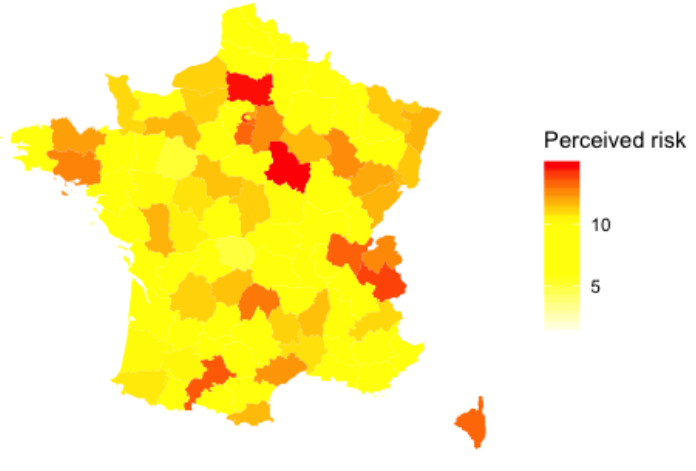

(a) Map of average perceived morbidity and mortality risk by department

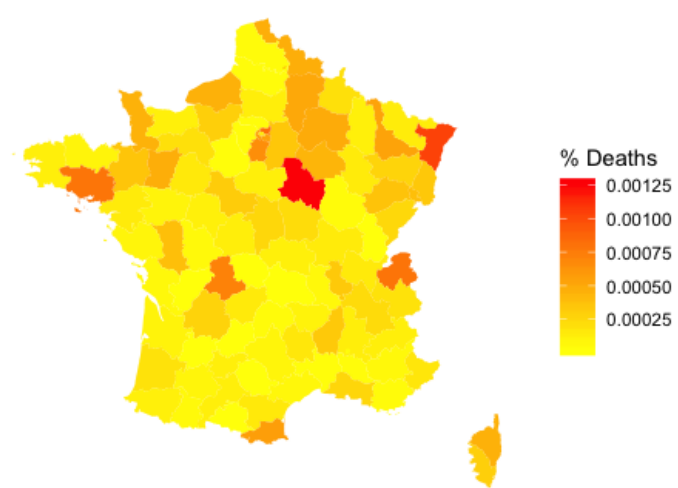

(b) Map of percentage deaths per department 
Figure 1. Map of COVID-19 deaths and perceived risk. Figure 1(a) shows the combined perceived risk of being infected, getting very sick or dying from COVID-19 in early June 2020. The data comes from the DataCovid Project, a citizen science initiative. Figure 1(b) shows the percentage of deaths from COVID-19 in the total population of each department in early June 2020. Data comes from the French government's official statistics.

Measure of patience and risk-taking. Each participant completed the time and risk preferences tasks developed by Falk et al (2016) (Falk et al., 2016). For the measure of patience, each participant had to choose between a sure payment today and a varying sure payment in 12 months in five different situations (e.g., Would you rather receive $100 €$ today or $150 €$ in 12 months?). The proposed amount for which the individual prefers the payment in 12 months over the payment today is then used to infer the individual's patience. Similarly for risk-taking, participants had to choose between a lottery and a varying safe option in five different situations (e.g., What would you prefer: a 50 percent chance of winning $300 €$ when at the same time there is 50 percent chance of winning nothing, or would you rather have the amount of $160 €$ as a sure payment?). The proposed amount for which the individual prefers the safe option to the lottery is then used to infer risk-taking. More details about the distribution of these variables can be found in the Appendix.

Measure of COVID-19 departmental prevalence. We collected data from the French health authorities in order to compute the cumulative number of individuals who (1) were infected with SARS-CoV-2, (2) were admitted in an intensive care unit as a result of COVID-19 and (3) died as a result of COVID-19 in each French department from the beginning of the pandemic to the time of our study. These numbers were publicly released by the health authorities on a regular basis. To measure risk exposure, we computed frequencies by dividing each of these numbers by the total population of each French department. Figure 1(b) displays the percentage of deaths from COVID-19 in each department. As expected, there was a lot of variation between departments during the first wave of the COVID-19 pandemic, with the Eastern and Parisian regions being most affected. 
Additional covariates. We expect that individuals form their perception of morbidity and mortality risk related to COVID-19 based on different sources of information, e.g., personal health characteristics (comorbidities, age, pregnancy, etc.), personal exposure to the virus (occupation, public transportation use, etc.) and experience with the disease (knowing someone who was sick or died as a result of being infected with SARS-CoV-2). For each participant, we recorded a number of demographic variables (age, gender, income, job status). A total of 511 participants selected "I prefer not say" for the question on income. We excluded these participants from our analysis. Each participant had to state whether they were a health worker and whether they worked outside during the lockdown (as opposed to individuals who were either put on furlough or remote workers). See Table 1 for more details.

\section{Results}

\section{Morbidity and mortality risk perception}

We first looked into the factors that influence people's morbidity and mortality risk perception by running an ordered probit model. We found that women perceive higher risk than men, although men are at higher risk of dying than women (Caramelo et al., 2020). We also found that older individuals perceive lower risk than younger individuals. This could be explained by the fact that older people, although they have higher morbidity and mortality risk if they become infected with SARS-CoV-2, are also less exposed to the virus because of social distancing. These results are similar to other studies related to risk perception during the COVID-19 pandemic. We also found that people take into account their occupation when forming their risk perception: Individuals working in the health sector, and individuals who worked outside (as opposed to working remotely or being on furlough) reported increased perceived morbidity and mortality risk $(\boldsymbol{\beta}=0.827$ and $\mathrm{p}=0.000$ and $\boldsymbol{\beta}=0.313, \mathrm{p}=0.000$, respectively, see Table 2). Finally, we also found that people took into account the incidence of COVID-19 in their department to form their risk perception. In particular, we found that the probability of reporting low perceived risk decreased with the percentage of COVID-19 related deaths in the department, while the probability of reporting high perceived death increased (see Figure 2). This finding demonstrates that people were sensitive to the departmental prevalence of the pandemic, i.e. that they use the available information on risk to form their own beliefs. 
Table 2. Perceived risk as an ordered probit model

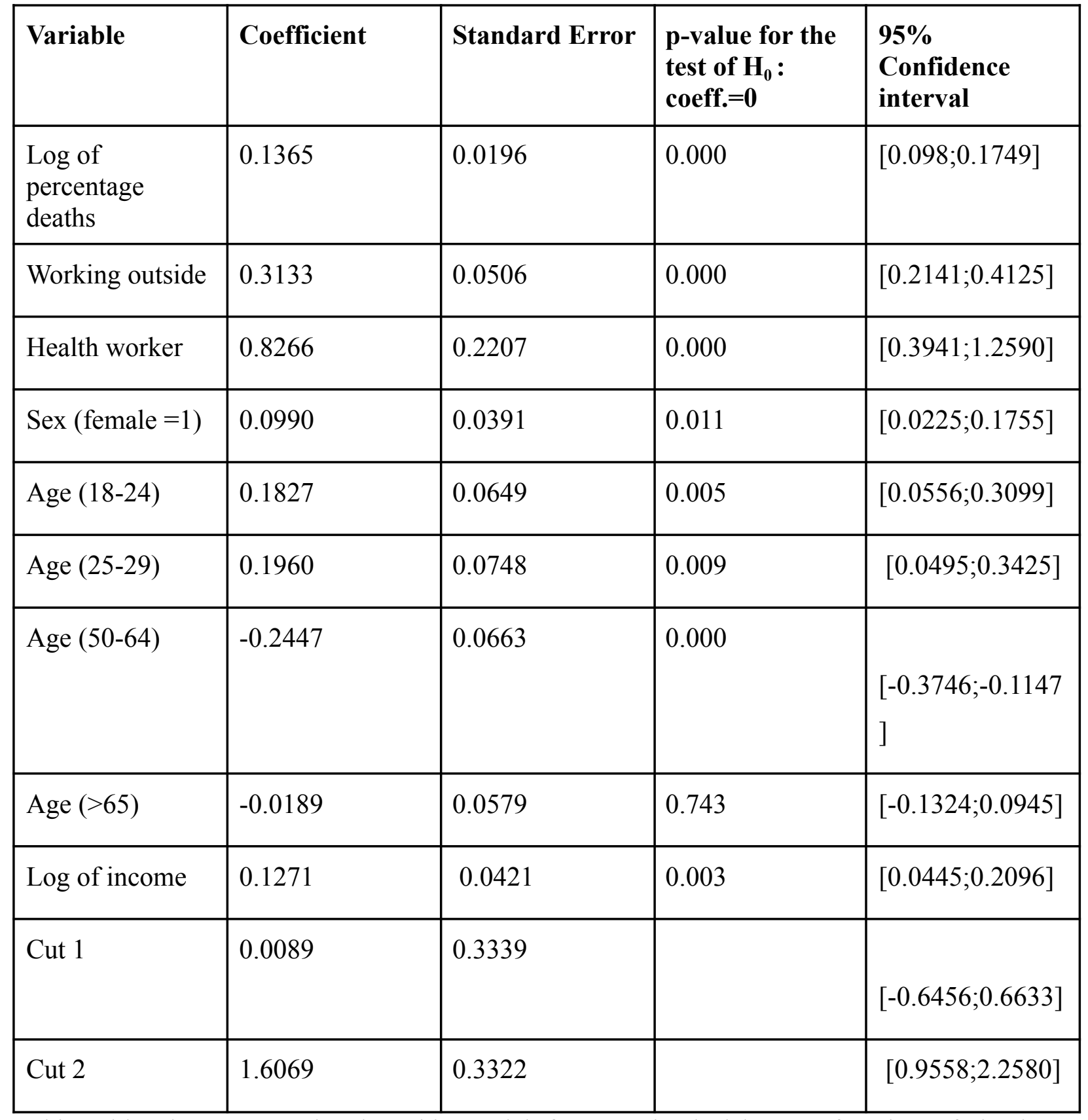

This table shows an ordered probit model for perceived risk as a function of the $\log$ of percentage deaths in the individual's department, whether that person worked outside of home during the first confinement, whether that person was a health worker, and a number of demographic variables. $\mathrm{N}=3,353$. We excluded participants who responded "I don't know" to one or more questions about perceived risk and respondents who responded "I prefer not say" for the question about their income. 


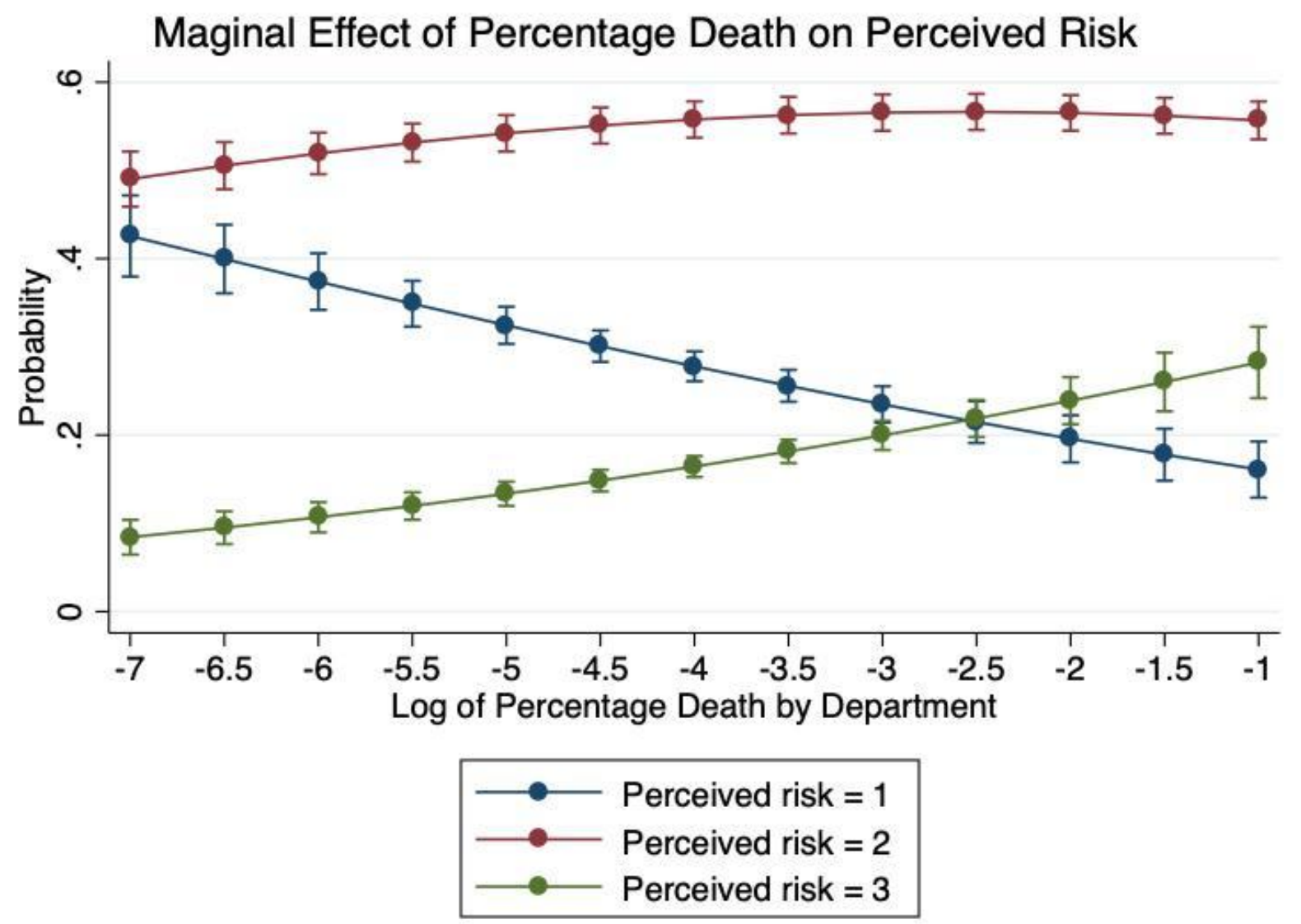

Figure 2. Marginal effect of the percentage of COVID-19 related deaths in the department on perceived morbidity and mortality risk. We find that the percentage of deaths had a negative marginal effect on the probability of perceiving a low risk, and a positive marginal effect on the probability of perceiving a high risk. There is no clear marginal effect on the probability of perceiving a medium risk. The bars represent the $95 \%$ confidence interval. $\mathrm{N}=$ 3,353 . We excluded participants who responded "I don't know" to one or more questions about perceived risk and respondents who responded "I prefer not say" for the question about their income.

\section{The effect of perceived risk on risk-taking and patience}

We then tested whether perceived morbidity and mortality risk affects risk-taking and patience. We first checked whether our measures of risk-taking and patience were consistent with the literature. Similarly to Falk et al. (2018), we found that women take fewer risks and are less patient, and that risk decreases with age. However, we did not find a positive correlation between 
age and patience or a negative correlation between age squared and risk-taking or patience. Consistent with other results in the literature, we found that risk-taking and patience increase with income (Boon-Falleur et al., 2021). Based on prior research, we predicted that individuals who are at risk of losing their job or of having their business go bankrupt would be less risk-taking and less patient (Malmendier \& Nagel, 2009). We regressed risk-taking and patience on the probability of losing one's job or going bankrupt while controlling for gender, age and income. In line with our hypothesis, we found that people who have a higher chance of losing their job were less risk-taking, although not significantly so $(\boldsymbol{\beta}=-0.001, \mathrm{p}=0.099)$, and significantly less patient $(\boldsymbol{\beta}=-0.004, \mathrm{p}=0.000)$. These analyses collectively suggest that our survey adequately measured risk-taking and patience.

Since perceived morbidity and mortality risk might be influenced by psychological traits that are likely correlated to risk-taking or patience, we cannot use it as an exogenous regressor. For instance, when regressing risk-taking and patience on perceived risk, we cannot know whether perceived morbidity and mortality risk affects time and risk preferences, or whether another factor such as anxiety affects both time and risk preferences and perceived morbidity and mortality risk. Hence a simple regression estimation through ordinary least squares is likely to yield biased estimates. To obtain a consistent estimate of the effect of subjective morbidity and mortality risk perception, we specified a two equation model explaining (1) how individuals build their subjective perceived risk on the basis of the released available information and (2) how this subjective risk influences risk-taking or patience.

$x_{i}=a Z_{d}+b W_{i}+\mu_{i, 1}$

$y_{j, i}=\beta_{j} x_{i}+\delta_{j} W_{i}+\varepsilon_{j, i}$

Where $x_{i}$ is the subjective morbidity and mortality risk perception, $Z_{d}$ is the percentage of COVID-19 related deaths in the department, $W_{i}$ is a vector of control variables, measured at the individual level (age, gender, income), and denoting $y_{1, i}$ the individual's time discounting factor and $y_{2, i}$ the individual's coefficient of risk aversion. In this model the non-exogeneity of subjective risk takes the form of a correlation $(\rho)$ between the disturbances of equations 1 and 2 . Estimating this model allows us to obtain consistent estimates even if perceived risk is non exogenous and to test its exogeneity through the test $\rho=0$. 
Given that subjective risk is a categorical variable, the first equation is specified as an ordered probit model estimated by the maximum likelihood estimator. The second equation is a simple linear model. To deal with the possible correlation between the disturbances of equations 1 and 2, we estimate our bivariate model with a maximum likelihood estimator, where the likelihood is written for the two equations at once. This approach leads to a consistent and efficient estimation. However, if the exogeneity of the subjective risk is not rejected, it is possible to use it directly in equation 2 without using the instrument provided by public information on risk. In this case it is preferable to use a semi-parametric approach such as ordinary least squares, as it is less constraining than the maximum likelihood, which is based on an assumption on the data generating process law.

Table 3: Estimation of a two-equation model explaining risk-taking as a function of perceived risk

\begin{tabular}{|l|l|l|l|l|}
\hline Variable & Coefficient & Standard Error & $\begin{array}{l}\text { p-value for the } \\
\text { test of } \mathbf{H}_{\mathbf{0}}: \\
\text { coeff.=0 }\end{array}$ & $\begin{array}{l}\text { 95\% } \\
\text { Confidence } \\
\text { interval }\end{array}$ \\
\hline Equation (2) & & & & \\
\hline Perceived risk & -1.1298 & 0.1184 & 0.000 & {$[-1.3618 ;-.8978]$} \\
\hline Sex (female =1) & -0.0647 & 0.0373 & 0.083 & {$[-0.1378 ; 0.0085]$} \\
\hline Age (18-24) & 0.3944 & 0.0840 & 0.000 & {$[0.2299 ; 0.5590]$} \\
\hline Age (25-29) & 0.3623 & 0.0754 & 0.000 & {$[0.2144 ; 0.5102]$} \\
\hline Age (50-64) & -0.3061 & 0.0807 & 0.000 & {$[-0.4643 ;-0.1478$} \\
]
\end{tabular}




\begin{tabular}{|l|l|l|l|l|}
\hline $\begin{array}{l}\text { percentage } \\
\text { deaths in } \\
\text { department }\end{array}$ & & & & \\
\hline Sex & 0.0893 & 0.0382 & 0.020 & {$[0.0143 ; 0.1642]$} \\
\hline Age $(18-24)$ & 0.1152 & 0.0674 & 0.087 & {$[-0.0169 ; 0.2472]$} \\
\hline Age (25-29) & 0.1951 & 0.0713 & 0.006 & {$[0.0553 ; 0.3348]$} \\
\hline Age (50-64) & -0.3647 & 0.0633 & 0.000 & $\begin{array}{l}{[-0.4887 ;-0.2406} \\
]\end{array}$ \\
\hline Age (>65) & -0.1836 & 0.0480 & 0.000 & {$[-0.2776 ;-0.0896$} \\
\hline Log of income & 0.1735 & 0.0411 & 0.000 & {$[0.0929 ; 0.2540]$} \\
\hline$\rho$ & 0.7433 & 0.0405 & & {$[0.6530 ; 0.8128]$} \\
\hline
\end{tabular}

Method: maximum likelihood estimator for the two-equation model, equation (1) explaining perceived risk as an ordered probit of the log of percentage of deaths in the department (bottom part of the table) and equation (2) explaining risk-taking as a function of perceived risk (top part of the table). We see that $\rho$ (the correlation coefficient between the disturbances of equations 1 and 2) is significantly positive, meaning that perceived risk is not exogenous. $\mathrm{N}=3,353$. We excluded participants who responded "I don't know" to one or more questions about perceived risk and respondents who responded "I prefer not say" for the question about their income.

Table 4: Estimation of a two-equation model explaining patience as a function of perceived risk

\begin{tabular}{|l|l|l|l|l|}
\hline Variable & Coefficient & Standard Error & $\begin{array}{l}\text { p-value for the } \\
\text { test of } \mathbf{H}_{\mathbf{0}}: \\
\text { coeff. } \mathbf{0}\end{array}$ & $\begin{array}{l}\mathbf{9 5 \%} \text { Confidence } \\
\text { interval }\end{array}$ \\
\hline Equation (2) & & & & \\
\hline Perceived risk & 0.1689 & 0.3907 & 0.666 & $\begin{array}{l}{[-0.5969 ; 0.9346} \\
]\end{array}$ \\
\hline Sex & -0.1723 & 0.0596 & 0.004 & $\begin{array}{l}{[-0.2891 ;-0.055} \\
6]\end{array}$ \\
\hline
\end{tabular}




$\left.\begin{array}{|l|l|l|l|l|}\hline \text { Age (18-24) } & 0.2280 & 0.1192 & 0.056 & {[-0.0056 ; 0.4617} \\ ]\end{array}\right]$

Method: maximum likelihood estimator for the two-equation model, equation (1) explaining perceived risk as an ordered probit of the log of percentage of deaths in the department (bottom part of the table) and equation (2) explaining patience as a function of perceived risk (top part of the table). We see that $\rho$ ( the correlation coefficient between the disturbances of equations 1 and 2) is not significantly different from zero, meaning that perceived risk is exogenous for patience. So, we must prefer a simple regression model. Indeed, in the case of exogeneity of the subjective risk, ordinary least squares are consistent like the maximum likelihood estimation, but more efficient). $\mathrm{N}=3,353$. We excluded participants who responded "I don't know" to one or more questions about perceived risk and respondents who responded "I prefer not say" for the question about their income. 
As expected, we found that higher perceived morbidity and mortality risk was associated with less risk-taking ( $\boldsymbol{\beta}=-1.13,95 \% \mathrm{CI}$ is $[-1.36 ;-0.90]$, see Table 3$)$. In addition, the coefficient $\rho$ was significantly different from zero $(\rho=.74,95 \%$ CI is $[0.65 ; 0.81])$, which shows that our structural model is consistent. To check the robustness of our results, we ran a similar model using a different specification for perceived risk and found similar results (see Appendix, Table A2).

For patience however, we found no significant effect of perceived morbidity and mortality risk $(\boldsymbol{\beta}=0.169, \mathrm{p}=0.666$, see Table 4$)$. The coefficient $\rho$ was not significantly different from zero $(\rho=-0.06,95 \%$ CI is $[-0.44 ; 0.35])$, which means that the perceived risk is exogenous and the structural model is not efficient. We therefore ran a simple regression of patience on perceived risk, treating perceived risk as a set of dummies to impose the fewest constraints on the model. We found that the relationship between perceived risk and patience was not consistent: higher perceived risk was associated with less patience when going from a medium perceived risk to a high perceived risk $(\boldsymbol{\beta}=-0.136, \mathrm{p}=0.022)$ but lower perceived risk was associated with less patience as compared to medium perceived risk $(\boldsymbol{\beta}=-0.0224, \mathrm{p}=0.000)$, see Table 5 . The fact that perceived morbidity and mortality risk is endogenous in the case of risk-taking and exogenous in the case of patience might seem surprising at first sight but it is conceivable that some psychological factors, such as anxiety, affect both perceived risk and risk-taking, while the same psychological factors do not affect patience. For instance, anxiety might affect how much an individual seeks official information on the prevalence of COVID-19 cases and thus increase how high that individual perceives her morbidity and mortality risk. Concomitantly, anxiety might affect an individual's actual risk-taking by influencing that individual's perception of the costs and benefits of taking risks (Huo et al., 2020; Nash et al., 2021). In the case of patience however, anxiety might be more orthogonal to people's willingness to wait for rewards. 
Table 5: Patience as a function of perceived risk

\begin{tabular}{|l|l|l|l|l|}
\hline Variable & Coefficient & Standard Error & $\begin{array}{l}\text { p-value for the } \\
\text { test of } \mathbf{H}_{\mathbf{0}}: \\
\text { coeff. } \mathbf{0}\end{array}$ & $\begin{array}{l}\mathbf{9 5 \%} \\
\text { Confidence } \\
\text { interval }\end{array}$ \\
\hline $\begin{array}{l}\text { Perceived risk }= \\
1\end{array}$ & -0.2238 & 0.0580 & 0.000 & $\begin{array}{l}{[-0.3389 ;-0.1087} \\
]\end{array}$ \\
\hline $\begin{array}{l}\text { Perceived risk }= \\
3\end{array}$ & -0.1355 & 0.0581 & 0.022 & $\begin{array}{l}{[-0.2510 ;-0.0201} \\
]\end{array}$ \\
\hline Sex & -0.1604 & 0.0565 & 0.006 & $\begin{array}{l}{[-0.2725 ;-0.0483} \\
]\end{array}$ \\
\hline Age (18-24) & 0.2058 & 0.1179 & 0.084 & {$[-0.0283 ; 0.4398]$} \\
\hline Age (25-29) & 0.2078 & 0.0879 & 0.020 & {$[0.0333 ; 0.3823]$} \\
\hline Age (50-64) & 0.0389 & 0.0824 & 0.638 & {$[-0.1247 ; 0.2025]$} \\
\hline Age (>65) & -0.1121 & 0.0559 & 0.048 & {$[-0.2231 ;-0.0010$} \\
]
\end{tabular}

Method: ordinary least squares. We regress patience on two dummies for perceived risk, one dummy for low perceived risk, and one dummy for high perceived risk. We find an inconclusive result: both lower and higher perceived risk seem to lead to lower patience. $\mathrm{N}=3,353$. We excluded participants who responded "I don't know" to one or more questions about perceived risk and respondents who responded "I prefer not say" for the question about their income.

\section{Discussion and Conclusion}

We found that morbidity and mortality risk perception depends not only on personal characteristics such as age, gender and occupation, but is also affected by the actual prevalence of the virus in people's departments. We then estimated a structural model to identify the effect 
of perceived risk on risk-taking and patience independently of other psychological traits. We found that, as expected, higher morbidity and mortality risk perception was associated with less risk-taking. In the case of patience, our results were inconclusive and more work should be done to gain a better understanding of the relationship between perceived risk and patience.

In the present research, we identified a novel effect. Previous studies focused on the impact of realized risk such as natural catastrophes or economic shocks. In contrast, our study shows that perceived risk, that is the anticipation of a negative event, can itself affect risk-taking and patience. This reveals in people a novel adaptive mechanism to potential future adversity. In addition, we also show that people form their expectations about morbidity and mortality risk in a rational way. The first months of the pandemic in France were characterized by a lot of country-level information about the prevalence of the virus and a desire from the government to make people weary of the risks associated with COVID-19. The fact that in such a context people were able to take into account very local information about the risk they were personally exposed to shows that, even in high-stress environments, people form rational expectations.

Is the effect of perceived morbidity and mortality risk durable? Our study took place after the first confinement in France, in June 2020. Since then, the French population has been exposed to another year of the pandemic and social distancing measures. It is possible that people have completely adapted to their new environment such that perceived morbidity and mortality risk no longer has an effect on their risk-taking and patience. In addition, what happens once there is no more morbidity and mortality risk, for example once the pandemic is over? Will people's risk-taking and patience revert to their pre-pandemic level, or will they be durably changed? Such questions should be addressed in future studies.

Given the central importance of risk preferences in decision-making, the COVID-19 pandemic might end up exerting indirect effects on multiple life choices, such as people's willingness to pursue certain types of careers or support certain policies (Dong, 2017). Individuals who expect a negative health shock may reduce their risk exposure in other domains of their life. This means that the covid pandemic may influence a wide range of choices. 


\section{Data Availability Statement}

The full database associated with the research, along with the materials, will be available to the public at the following address https://osf.io/k9uay/. In addition, official statistics are available on the government website:

https://www.data.gouv.fr/fr/datasets/donnees-hospitalieres-relatives-a-lepidemie-de-COVID-19/ and the raw data collected by the Datacovid citizen project can be downloaded on their website: https://datacovid.org/data/ under "Vague 8".

\section{Code availability statement}

The STATA scripts to reproduce the analyses presented in the current research will be made available to the public at the following address: https://osf.io/k9uay/.

\section{Acknowledgment}

This study was supported by the EUR FrontCog grant ANR-17-EURE-0017*, by an ANR grant (grantcode: BEHAVIRAL) and by the Datacovid network.

\section{Author contributions}

Mélusine Boon-Falleur: Conceptualisation, Methodology, Formal Analysis, Writing - Original Draft, Writing - Review \& Editing. Brigitte Dormont: Conceptualisation, Methodology, Formal Analysis, Writing - Review \& Editing, Funding acquisition. Coralie Chevallier: Conceptualisation, Methodology, Writing - Original Draft, Writing - Review \& Editing, Funding acquisition

\section{Competing interests}

None. 


\section{References}

Amir, D., Jordan, M. R., \& Rand, D. G. (2018). An uncertainty management perspective on long-run impacts of adversity: The influence of childhood socioeconomic status on risk, time, and social preferences. Journal of Experimental Social Psychology, 79, 217-226. https://doi.org/10.1016/j.jesp.2018.07.014

Boon-Falleur, M., Baumard, N., \& André, J.-B. (2021). Risk-seeking or impatient? Disentangling variance and time in hazardous behaviors. Evolution and Human Behavior, S1090513821000271. https://doi.org/10.1016/j.evolhumbehav.2021.04.001

Callen, M. (2015). Catastrophes and time preference: Evidence from the Indian Ocean Earthquake. Journal of Economic Behavior \& Organization, 118, 199-214. https://doi.org/10.1016/j.jebo.2015.02.019

Callen, M., Isaqzadeh, M., Long, J. D., \& Sprenger, C. (2014). Violence and Risk Preference: Experimental Evidence from Afghanistan. American Economic Review, 104(1), 123-148. https://doi.org/10.1257/aer.104.1.123

Caramelo, F., Ferreira, N., \& Oliveiros, B. (2020). Estimation of risk factors for COVID-19 mortality—Preliminary results [Preprint]. Epidemiology. https://doi.org/10.1101/2020.02.24.20027268

Cassar, A., Healy, A., \& von Kessler, C. (2017). Trust, Risk, and Time Preferences After a Natural Disaster: Experimental Evidence from Thailand. World Development, 94, 90-105. https://doi.org/10.1016/j.worlddev.2016.12.042

Ciancio, A., Delavande, A., Kohler, H.-P., \& Kohler, I. V. (2020). Mortality Risk Information, Survival Expectations and Sexual Behaviors. Penn Population Center Working Paper 2020-39, 79.

Decker, S., \& Schmitz, H. (2016). Health shocks and risk aversion. Journal of Health Economics, 50, 156-170. https://doi.org/10.1016/j.jhealeco.2016.09.006

Dong, H.-K. D. (2017). Individual Risk Preference and Sector Choice: Are Risk-Averse Individuals More Likely to Choose Careers in the Public Sector? - Hsiang-Kai Dennis Dong, 2017. Administration 
\& Society, 49(8), 1121-1142. https://doi.org/10.1177/0095399714556500

Douglas, M., \& Wildavsky, A. (1983). Risk and Culture. In Risk and Culture. University of California Press. https://www.degruyter.com/document/doi/10.1525/9780520907393/html

Falk, A., Becker, A., Dohmen, T., Huffman, D., \& Sunde, U. (2016). The Preference Survey Module: A Validated Instrument for Measuring Risk, Time, and Social Preferences. IZA Discussion Paper No. 9674,69 .

Guiso, L., Sapienza, P., \& Zingales, L. (2018). Time Varying Risk Aversion. Journal of Financial Economics, 128(3), 403-421.

Hanaoka, C., Shigeoka, H., \& Watanabe, Y. (2018). Do Risk Preferences Change? Evidence from Panel Data before and after the Great East Japan Earthquake. American Economic Journal: Applied Economics, 10(2), 298-330.

Horvath, G., Martin, J., Lopez, P., Garamszegi, L. Z., Bertok, P., \& Herczeg, G. (2016). Blood Parasite Infection Intensity Covaries with Risk-Taking Personality in Male Carpetan Rock Lizards. Ethology, 122(5), 355-363. https://doi.org/10.1111/eth.12475

Huo, H., Zhang, R., Seger, C. A., Feng, T., \& Chen, Q. (2020). The effect of trait anxiety on risk-taking: Functional coupling between right hippocampus and left insula. Psychophysiology, 57(10), e13629. https://doi.org/10.1111/psyp.13629

Joffe, H. (2003). Risk: From perception to social representation. British Journal of Social Psychology, 42(1), 55-73. https://doi.org/10.1348/014466603763276126

Kettlewell, N., Rijsdijk, F., Siribaddana, S., Sumathipala, A., Tymula, A., Zavos, H., \& Glozier, N. (2018). Civil War, Natural Disaster and Risk Preferences: Evidence from Sri Lankan Twins. IZA Discussion Paper No. 11901, 47.

Leiserowitz, A. (2006). Climate Change Risk Perception and Policy Preferences: The Role of Affect, Imagery, and Values. Climatic Change, 77(1), 45-72. https://doi.org/10.1007/s10584-006-9059-9

Loewenstein, G., \& Angner, E. (2003). Predicting and indulging changing preferences. In Time and decision: Economic and psychological perspectives on intertemporal choic (pp. 351-391). 
Russell Sage Foundation Press.

Loewenstein, G. F., Weber, E. U., Hsee, C. K., \& Welch, N. (2001). Risk as feelings. Psychological Bulletin, 127(2), 267-286. https://doi.org/10.1037/0033-2909.127.2.267

Malmendier, U., \& Nagel, S. (2009). Depression babies: Do macroeconomic experiences affect risk-taking? NBER Working Paper, 14813.

Marinov, M. P., Zehtindjiev, P., Dimitrov, D., Ilieva, M., Bobeva, A., \& Marchetti, C. (2017).

Haemosporidian infections and host behavioural variation: A case study on wild-caught nightingales ( Luscinia megarhynchos ). Ethology Ecology \& Evolution, 29(2), 126-137. https://doi.org/10.1080/03949370.2015.1102776

Mishra, S. (2014). Decision-Making Under Risk: Integrating Perspectives From Biology, Economics, and Psychology. Personality and Social Psychology Review, 18(3), 280-307. https://doi.org/10.1177/1088868314530517

Mishra, S., \& Lalumière, M. L. (2010). You can't always get what you want: The motivational effect of need on risk-sensitive decision-making. Journal of Experimental Social Psychology, 46(4), 605-611. https://doi.org/10.1016/j.jesp.2009.12.009

Nash, K., Leota, J., \& Tran, A. (2021). Neural processes in antecedent anxiety modulate risk-taking behavior. Scientific Reports, 11(1), 2637. https://doi.org/10.1038/s41598-021-82229-w

Page, L., Savage, D. A., \& Torgler, B. (2014). Variation in risk seeking behaviour following large losses: A natural experiment. European Economic Review, 71, 121-131. https://doi.org/10.1016/j.euroecorev.2014.04.009

Pepper, G. V., \& Nettle, D. (2013). Death and the time of your life: Experiences of close bereavement are associated with steeper financial future discounting and earlier reproduction. Evolution and Human Behavior, 34(6), 433-439. https://doi.org/10.1016/j.evolhumbehav.2013.08.004

Pepper, G. V., \& Nettle, D. (2014a). Out of control mortality matters: The effect of perceived uncontrollable mortality risk on a health-related decision. PeerJ, 2. https://doi.org/10.7717/peerj.459 
Pepper, G. V., \& Nettle, D. (2014b). Perceived Extrinsic Mortality Risk and Reported Effort in Looking after Health. Human Nature, 25(3), 378-392. https://doi.org/10.1007/s12110-014-9204-5

Pepper, G. V., \& Nettle, D. (2017). The behavioural constellation of deprivation: Causes and consequences. Behavioral and Brain Sciences, 40. https://doi.org/10.1017/S0140525X1600234X

Phillips, P., \& Hansen, B. (1990). Statistical Inference in Instrumental Variables Regression with I(1) Processes. Review of Economic Studies, 57(1), 99-125.

Prokosch, M. L., Gassen, J., Ackerman, J. M., \& Hill, S. E. (2019). Caution in the time of cholera: Pathogen threats decrease risk tolerance. Evolutionary Behavioral Sciences, 13(4), 311-334. https://doi.org/10.1037/ebs0000160

Safra, L., Sijilmassi, A., \& Chevallier, C. (2021). Disease, perceived infectability and threat reactivity: A COVID-19 study. Personality and Individual Differences, 180, 110945. https://doi.org/10.1016/j.paid.2021.110945

Slovic, P. (1987). Perception of Risk. Science, 236(4799), 280-285.

Slovic, P., Fischhoff, B., \& Lichtenstein, S. (1982). Why Study Risk Perception? Risk Analysis, 2(2), 11. Stephens D. W., A. B. (1981). The Logic of Risk-Sensitive Foraging Preferences. Animal Behaviour, 29(2), 628-629. https://doi.org/10.1016/S0003-3472(81)80129-7

van der Linden, S. (2015). The social-psychological determinants of climate change risk perceptions: Towards a comprehensive model. Journal of Environmental Psychology, 41, 112-124. https://doi.org/10.1016/j.jenvp.2014.11.012

Xiong, J., Lipsitz, O., Nasri, F., Lui, L. M. W., Gill, H., Phan, L., Chen-Li, D., Iacobucci, M., Ho, R., Majeed, A., \& McIntyre, R. S. (2020). Impact of COVID-19 pandemic on mental health in the general population: A systematic review. Journal of Affective Disorders, 277, 55-64. https://doi.org/10.1016/j.jad.2020.08.001 


\section{Appendix}

\section{Data Description}

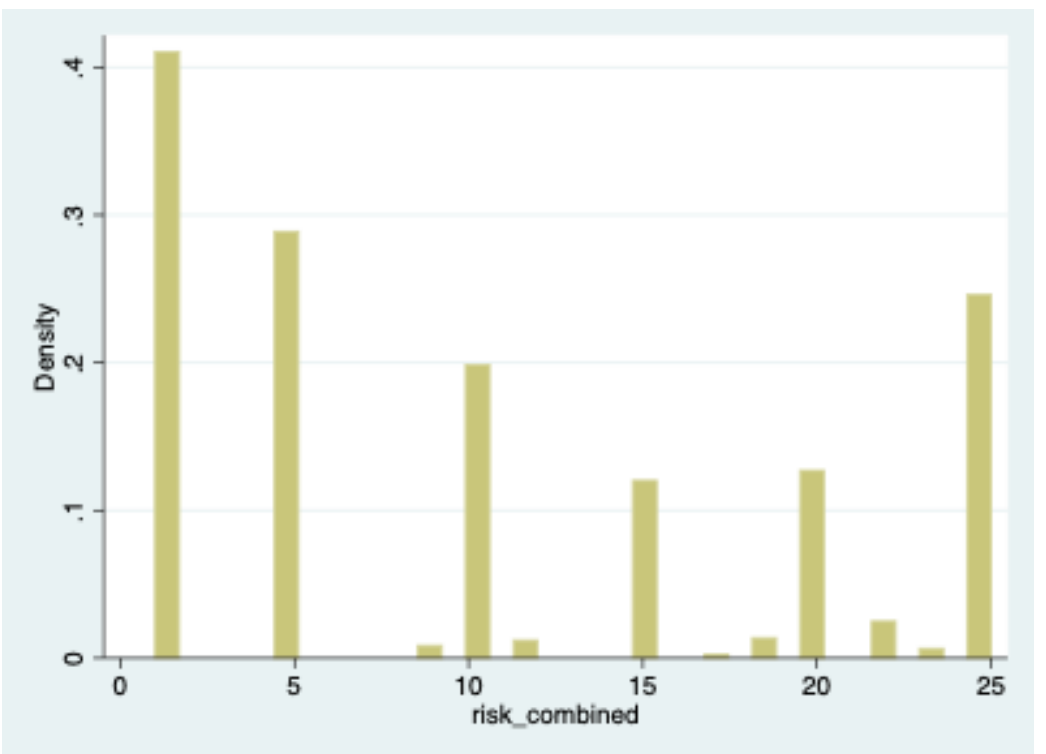

Figure A1. Histogram of the combined perceived risk $(\mathrm{N}=3,642$, we excluded participants who answered "I don't know" to one or more questions about perceived risk).

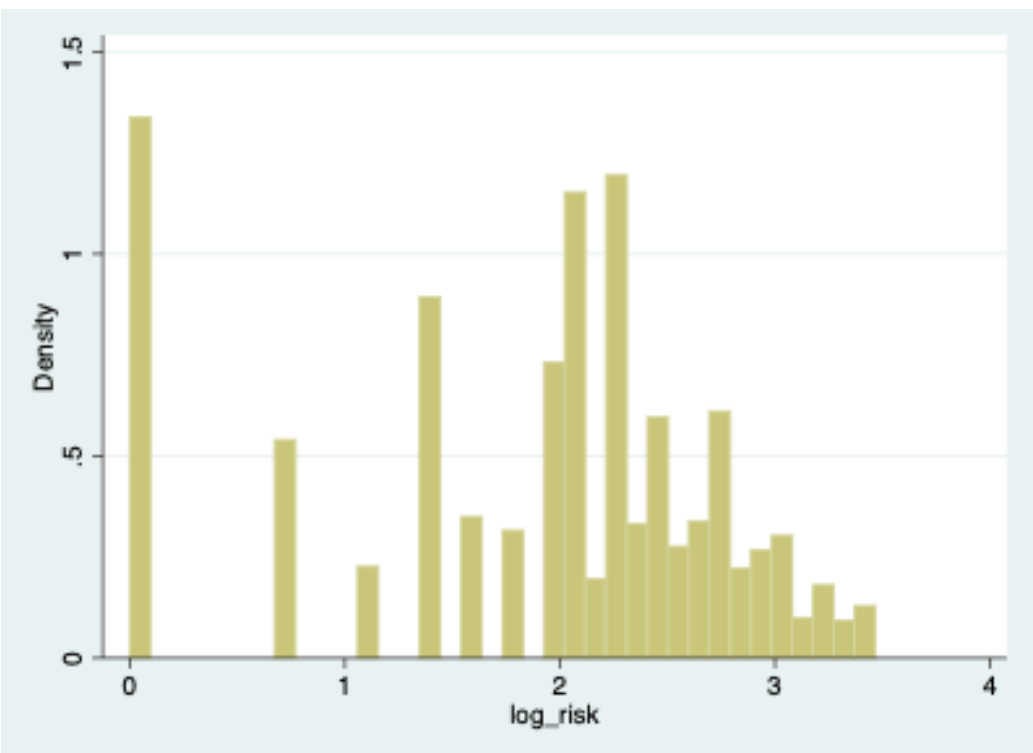

Figure A2. Histogram of the log of risk-taking $(\mathrm{N}=5,000)$. 


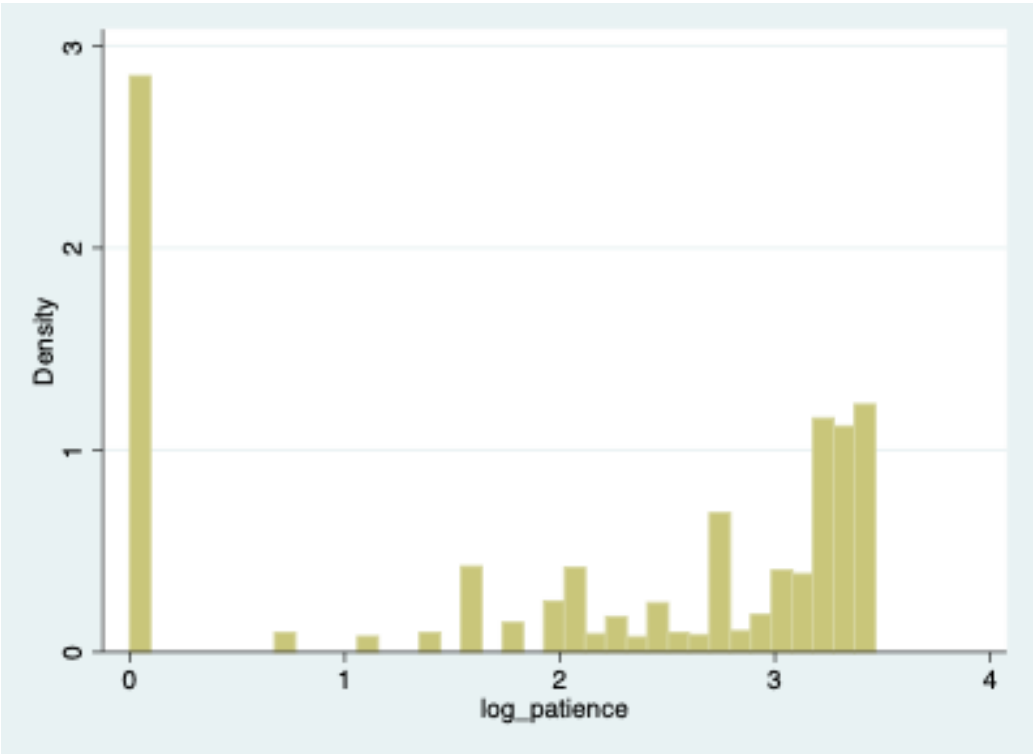

Figure A3. Histogram of the log of patience $(\mathrm{N}=5,000)$.

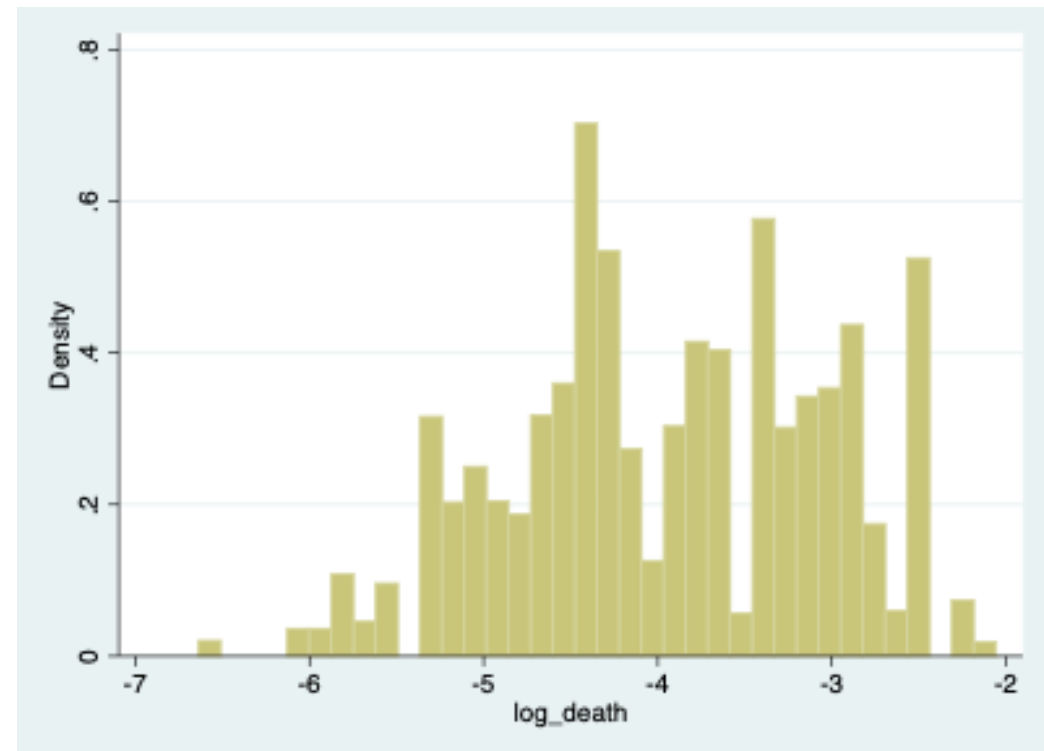

Figure A4. Histogram of the log of the percentage of deaths by department for each participant $(\mathrm{N}=5,000)$.

\section{Data Analysis}

Robust
log_risk $\mid \quad$ Coef. Std. Err. $\quad t \quad P>|t| \quad$ [95\% Conf. Interval]


COVID-19 and risk and time preferences

\begin{tabular}{r|rrrrrr} 
perceived_risk_low & -.1683564 & .0355601 & -4.73 & 0.000 & -.2389522 & -.0977607 \\
perceived_risk_high & -.0749232 & .0405414 & -1.85 & 0.068 & -.155408 & .0055616 \\
sex & -.1169951 & .030285 & -3.86 & 0.000 & -.1771185 & -.0568717 \\
age_18_24 & .2917392 & .0710574 & 4.11 & 0.000 & .1506723 & .432806 \\
age_25_29 & .218078 & .0548129 & 3.98 & 0.000 & .1092607 & .3268953 \\
age_50_64 & -.0551212 & .0516553 & -1.07 & 0.289 & -.1576699 & .0474276 \\
age_65 & -.0922039 & .0406374 & -2.27 & 0.026 & -.1728793 & -.0115284 \\
log_income $\mid$ & .210344 & .0399397 & 5.27 & 0.000 & .1310537 & .2896344 \\
_cons & .3918133 & .3230535 & 1.21 & 0.228 & -.249529 & 1.033156
\end{tabular}

Table A1. We run a linear regression model of risk-taking on perceived morbidity and mortality risk (two dummy variables, low perceived risk and high perceived risk). We find that a negative effect of high perceived risk, however it is not significant at $5 \%$. We also find a negative effect for low perceived risk, which is contrary to our prediction. However, these results are not convergent.

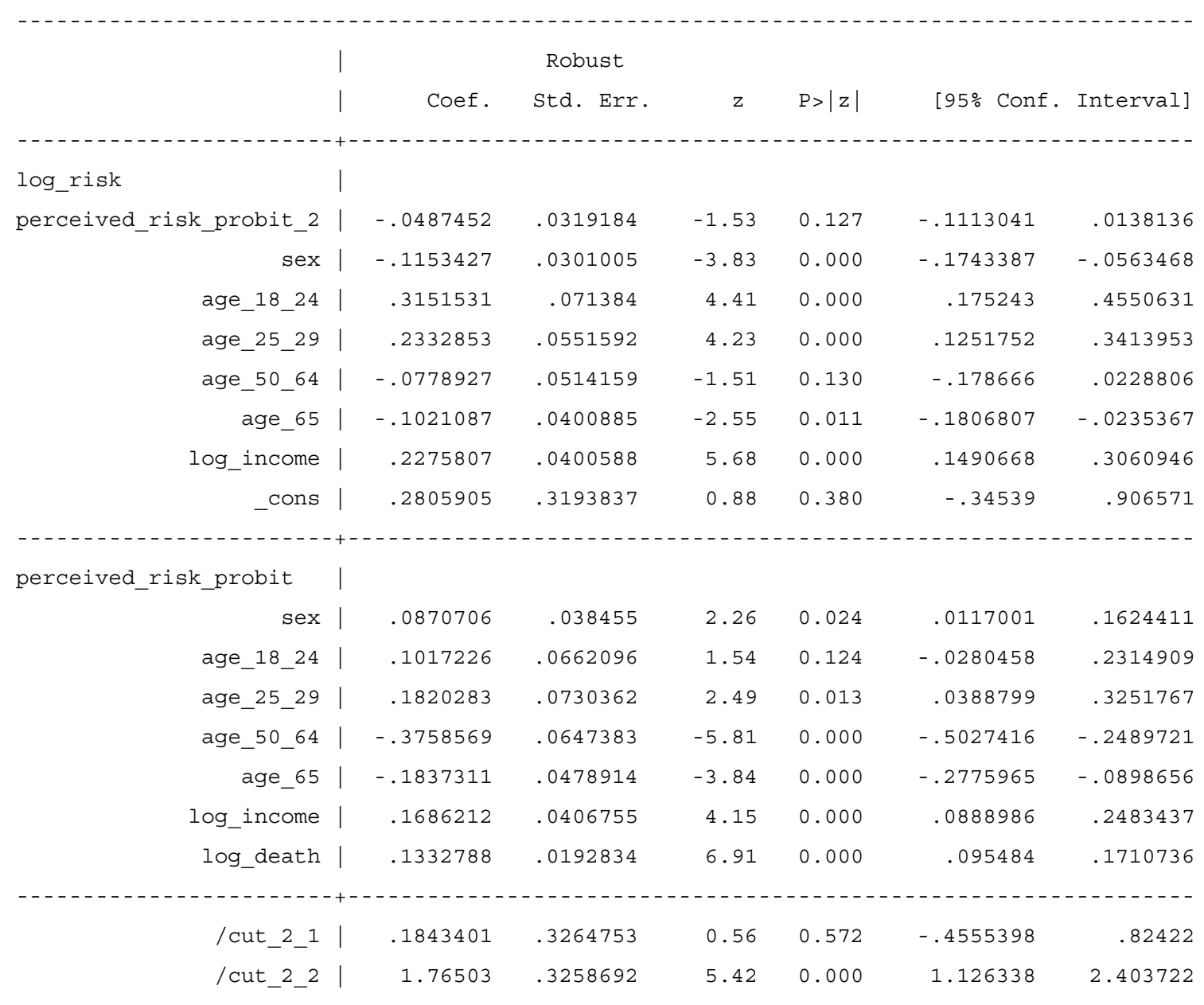


COVID-19 and risk and time preferences

\begin{tabular}{|c|c|c|c|c|c|c|}
\hline /lnsig_1 | & -.109678 & .012411 & -8.84 & 0.000 & -.134003 & -.0853529 \\
\hline /atanhrho_12 | & .0935226 & .031582 & 2.96 & 0.003 & .0316231 & .1554222 \\
\hline sig_1 | & .8961227 & .0111218 & & & .8745874 & .9181882 \\
\hline rho_12 | & .0932509 & .0313074 & & & .0316125 & .1541827 \\
\hline
\end{tabular}

Table A2. Structural model for risk-taking and perceived risk. We run the structural model to evaluate the impact of perceived risk on risk-taking. To ensure the robustness of our results, we change the specification for perceived-risk. We define a categorical variable with three values: low perceived risk (1\% and 5\%), medium perceived risk (between 5\% and 25\%), and high perceived risk (25\%). We find again a negative effect of perceived morbidity and mortality risk on risk-taking, however this effect is not significant.

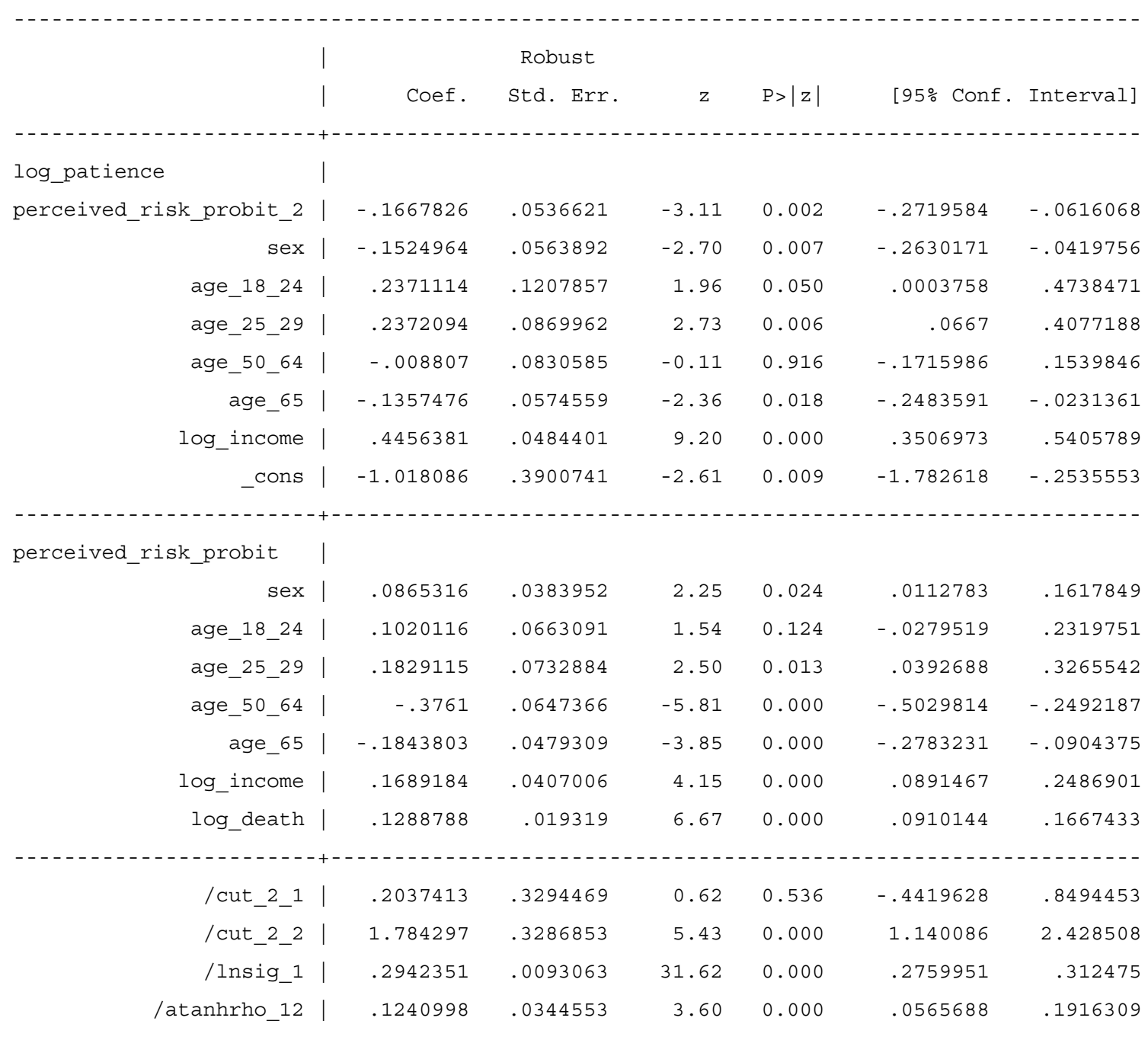




$\begin{array}{rrrrr}\text { sig_1 } & 1.342099 & .01249 & 1.317841 & 1.366804 \\ \text { rho_12 } & .1234666 & .03393 & .0565085 & .1893191\end{array}$

Table A3. Structural model for patience and perceived risk. We run the structural model to evaluate the impact of perceived risk on patience. To ensure the robustness of our results, we change the specification for perceived-risk. We define a categorical variable with three values: low perceived risk (1\% and 5\%), medium perceived risk (between 5\% and 25\%), and high perceived risk (25\%). We find this time a significant negative effect of perceived morbidity and mortality risk on patience, and we find that perceived risk is not exogenous.

\begin{tabular}{|c|c|c|c|c|c|c|}
\hline $\mid$ & \multicolumn{3}{|c|}{ Robust } & & \multirow[b]{2}{*}{$95 \%$ Conf. } & \multirow[b]{2}{*}{ Interval] } \\
\hline | & Coef. & Std. Err. & z & $\mathrm{P}>|\mathrm{z}|$ & & \\
\hline \multicolumn{7}{|l|}{ log_risk } \\
\hline perceived_risk_probit | & -1.129974 & .1156517 & -9.77 & 0.000 & -1.356647 & -.9033006 \\
\hline $\operatorname{sex} \mid$ & -.0646477 & .0372965 & -1.73 & 0.083 & -.1377474 & .0084521 \\
\hline age_18_24 | & .3944578 & .0839008 & 4.70 & 0.000 & .2300153 & .5589003 \\
\hline age_25_29 | & .3623233 & .0754071 & 4.80 & 0.000 & .2145282 & .5101185 \\
\hline age_50_64 | & -.3061185 & .0804628 & -3.80 & 0.000 & -.4638227 & -.1484144 \\
\hline age_65 | & -.2229056 & .0477873 & -4.66 & 0.000 & -.3165671 & -.1292442 \\
\hline log_income | & .3407182 & .0518685 & 6.57 & 0.000 & .2390577 & .4423786 \\
\hline _cons | & 1.454809 & .3913288 & 3.72 & 0.000 & .6878182 & 2.221799 \\
\hline \multicolumn{7}{|l|}{ perceived_risk_probit | } \\
\hline sex & .0893787 & .0383415 & 2.33 & 0.020 & .0142308 & .1645267 \\
\hline age_18_24 | & .1149931 & .0675316 & 1.70 & 0.089 & -.0173663 & .2473525 \\
\hline age_25_29 | & .1931645 & .0713068 & 2.71 & 0.007 & .0534058 & .3329232 \\
\hline age_50_64 | & -.3629028 & .0634065 & -5.72 & 0.000 & -.4871772 & -.2386285 \\
\hline age_65 | & -.18581 & .0479239 & -3.88 & 0.000 & -.2797392 & -.0918809 \\
\hline log_income | & .1742573 & .0411963 & 4.23 & 0.000 & .093514 & .2550005 \\
\hline log_hospitalized | & .1009342 & .0174294 & 5.79 & 0.000 & .0667732 & .1350951 \\
\hline & & & ---- & & $-\ldots-\ldots$ & 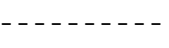 \\
\hline /cut_2_1 | & .5599114 & .3339538 & 1.68 & 0.094 & -.0946261 & 1.214449 \\
\hline /cut_2_2 | & 2.114649 & .3318253 & 6.37 & 0.000 & 1.464284 & 2.765015 \\
\hline /lnsig_1 | & .1695712 & .0434931 & 3.90 & 0.000 & .0843263 & .2548162 \\
\hline /atanhrho_12 | & .9579616 & .0892605 & 10.73 & 0.000 & .7830143 & 1.132909 \\
\hline sig_1 & 1.184797 & .0515305 & & & 1.087984 & 1.290224 \\
\hline rho_12 | & .7433663 & .0399357 & & & .6544334 & .8120125 \\
\hline
\end{tabular}


Table A4. Structural model for risk-taking and perceived risk. We run the structural model to evaluate the impact of perceived risk on risk-taking. To ensure the robustness of our results, we change our instrument. Instead of using the percentage of deaths in a department, we use the percentage of hospitalisation. We find similar results using this new instrument.

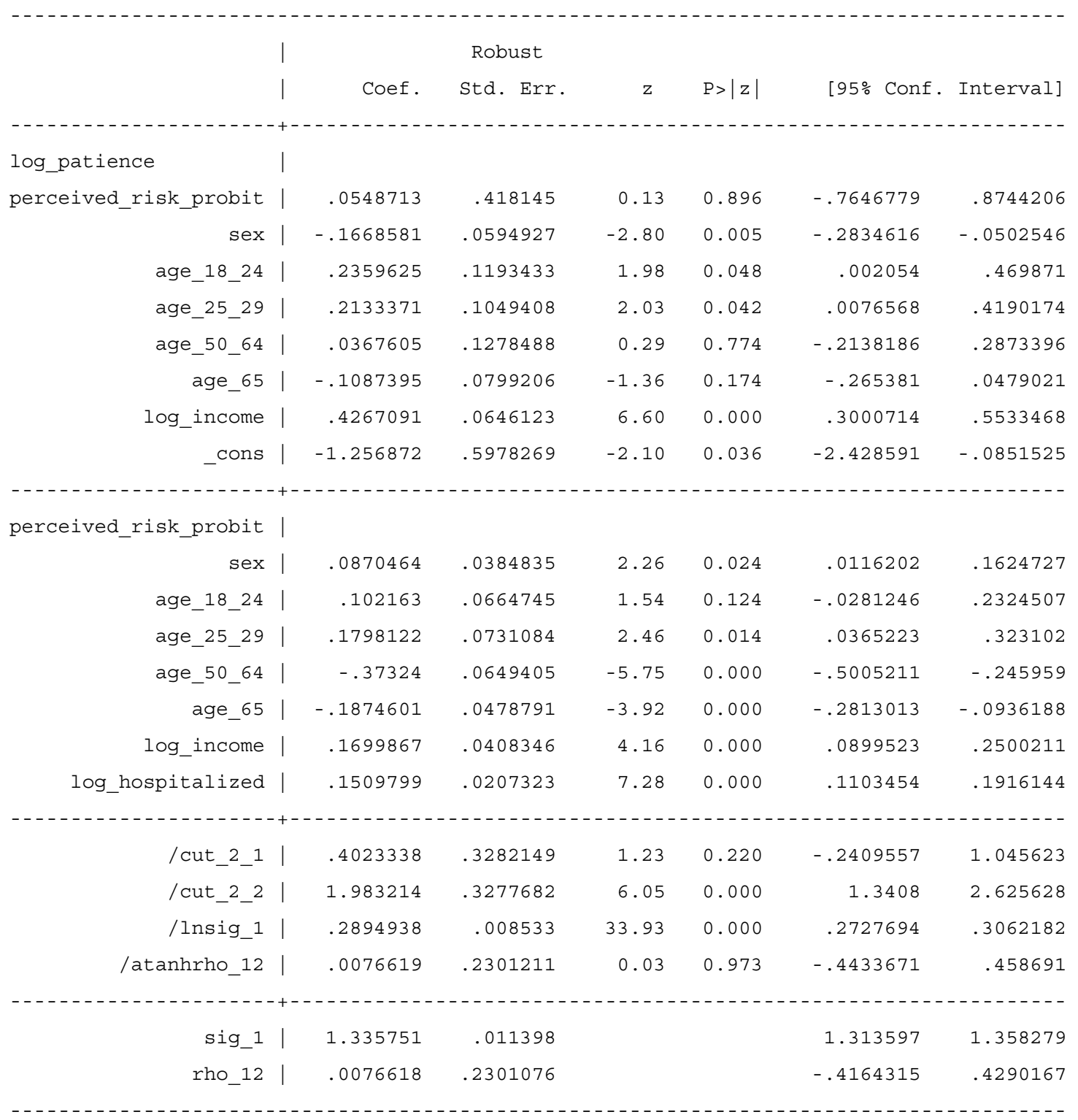

Table A5. Structural model for patience and perceived risk. We run the structural model to evaluate the impact of perceived risk on patience. To ensure the robustness of our results, we change our instrument. Instead of using the percentage of deaths in a department, we use the percentage of hospitalisation. We find similar results using this new instrument. 


\begin{tabular}{|c|c|c|c|c|c|c|}
\hline Robust & & & & & & \\
\hline log_patience | & Coef. & Std. Err. & t & $P>|t|$ & {$[95 \%$ Conf. } & Interval] \\
\hline perceived_risk_low_2 | & -.0667201 & .0471977 & -1.41 & 0.161 & -.1604195 & .0269793 \\
\hline perceived_risk_high | & -.0999451 & .0589525 & -1.70 & 0.093 & -.2169807 & .0170904 \\
\hline $\operatorname{sex} \mid$ & -.1621819 & .0562012 & -2.89 & 0.005 & -.2737553 & -.0506085 \\
\hline age_18_24 | & .2322829 & .1194809 & 1.94 & 0.055 & -.0049166 & .4694825 \\
\hline age_25_29 | & .2196515 & .0879855 & 2.50 & 0.014 & .0449781 & .3943248 \\
\hline age_50_64 | & .0232803 & .0820491 & 0.28 & 0.777 & -.1396077 & .1861684 \\
\hline age_65 | & -.1169019 & .056134 & -2.08 & 0.040 & -.2283419 & -.0054619 \\
\hline log_income | & .4298788 & .0479314 & 8.97 & 0.000 & .334723 & .5250346 \\
\hline _cons | & -1.128958 & .3879242 & -2.91 & 0.004 & -1.899085 & -.3588309 \\
\hline
\end{tabular}

Table A6. Linear model for patience and perceived risk. Table S1. We run a linear regression model of patience on perceived morbidity and mortality risk (two dummy variables, low perceived risk and high perceived risk). To ensure the robustness of our results, we change the specification of perceived risk. We define a categorical variable with three values: low perceived risk (1\% and 5\%), medium perceived risk (between 5\% and 25\%), and high perceived risk $(25 \%)$. We find similar results.

\section{Materials}


Table A7. Measure of time discounting. Each participant was asked to answer a series of five questions from a list of 31 hypothetical choices between an early payment "today" (100€) and a varying delayed payment "in 12 months" (starting at $103 €$ and increasing to $215 €$ in increments of $3-4 €)$. To determine the alternatives given to an individual, we implemented a "staircase" procedure. Depending on the individual's answer (payment today or in 12 months), she was given a higher or lower option in 12 months in order to find the smallest amount in 12 months for which the participant preferred the amount in 12 months to the amount today.

\begin{tabular}{|c|c|c|}
\hline Number & Question & Answer and next question \\
\hline Q.2.1 & $\begin{array}{l}\text { Please consider the following: would you rather } \\
\text { receive } 100 \text { Euro today or } 154 \text { Euro in } 12 \\
\text { months? }\end{array}$ & $\begin{array}{l}=\text { Today } \rightarrow \text { Go to question } 2.17 \\
=\text { In } 12 \text { months } \rightarrow \text { Go to } \\
\text { question } 2.2\end{array}$ \\
\hline Q.2.2 & $\begin{array}{l}\text { Would you rather receive } 100 \text { Euro today or } 125 \\
\text { Euro in } 12 \text { months? }\end{array}$ & $\begin{array}{l}=\text { Today } \rightarrow \text { Go to question } 2.10 \\
=\text { In } 12 \text { months } \rightarrow \text { Go to } \\
\text { question } 2.3\end{array}$ \\
\hline Q.2.3 & $\begin{array}{l}\text { Would you rather receive } 100 \text { Euro today or } 112 \\
\text { Euro in } 12 \text { months? }\end{array}$ & $\begin{array}{l}=\text { Today } \rightarrow \text { Go to question } 2.7 \\
=\text { In } 12 \text { months } \rightarrow \text { Go to } \\
\text { question } 2.4\end{array}$ \\
\hline Q.2.4 & $\begin{array}{l}\text { Would you rather receive } 100 \text { Euro today or } 106 \\
\text { Euro in } 12 \text { months? }\end{array}$ & $\begin{array}{l}=\text { Today } \rightarrow \text { Go to question } 2.6 \\
=\text { In } 12 \text { months } \rightarrow \text { Go to } \\
\text { question } 2.5\end{array}$ \\
\hline Q.2.5 & $\begin{array}{l}\text { Would you rather receive } 100 \text { Euro today or } 103 \\
\text { Euro in } 12 \text { months? }\end{array}$ & $\begin{array}{l}=\text { Today }[\text { Final question] } \\
=\text { In } 12 \text { months }[\text { Final question] }\end{array}$ \\
\hline Q.2.6 & $\begin{array}{l}\text { Would you rather receive } 100 \text { Euro today or } 109 \\
\text { Euro in } 12 \text { months? }\end{array}$ & $\begin{array}{l}=\text { Today [Final question] } \\
=\text { In } 12 \text { months [Final question] }\end{array}$ \\
\hline Q.2.7 & $\begin{array}{l}\text { Would you rather receive } 100 \text { Euro today or } 119 \\
\text { Euro in } 12 \text { months? }\end{array}$ & $\begin{array}{l}=\text { Today } \rightarrow \text { Go to question } 2.8 \\
=\text { In } 12 \text { months } \rightarrow \text { Go to } \\
\text { question } 2.9\end{array}$ \\
\hline Q.2.8 & $\begin{array}{l}\text { Would you rather receive } 100 \text { Euro today or } 122 \\
\text { Euro in } 12 \text { months? }\end{array}$ & $\begin{array}{l}=\text { Today }[\text { Final question] } \\
=\text { In } 12 \text { months }[\text { Final question] }\end{array}$ \\
\hline Q.2.9 & $\begin{array}{l}\text { Would you rather receive } 100 \text { Euro today or } 116 \\
\text { Euro in } 12 \text { months? }\end{array}$ & $\begin{array}{l}=\text { Today [Final question] } \\
=\text { In } 12 \text { months }[\text { Final question] }\end{array}$ \\
\hline
\end{tabular}




\begin{tabular}{|c|c|c|}
\hline Q.2.10 & $\begin{array}{l}\text { Would you rather receive } 100 \text { Euro today or } 139 \\
\text { Euro in } 12 \text { months? }\end{array}$ & $\begin{array}{l}=\text { Today } \rightarrow \text { Go to question } 2.14 \\
=\text { In } 12 \text { months } \rightarrow \text { Go to } \\
\text { question } 7.11\end{array}$ \\
\hline Q.2.11 & $\begin{array}{l}\text { Would you rather receive } 100 \text { Euro today or } 132 \\
\text { Euro in } 12 \text { months? }\end{array}$ & $\begin{array}{l}=\text { Today } \rightarrow \text { Go to question } 2.13 \\
=\text { In } 12 \text { months } \rightarrow \text { Go to } \\
\text { question } 2.12\end{array}$ \\
\hline Q.2.12 & $\begin{array}{l}\text { Would you rather receive } 100 \text { Euro today or } 129 \\
\text { Euro in } 12 \text { months? }\end{array}$ & $\begin{array}{l}=\text { Today [Final question] } \\
=\text { In } 12 \text { months [Final question] }\end{array}$ \\
\hline Q.2.13 & $\begin{array}{l}\text { Would you rather receive } 100 \text { Euro today or } 136 \\
\text { Euro in } 12 \text { months? }\end{array}$ & $\begin{array}{l}=\text { Today [Final question] } \\
=\text { In } 12 \text { months [Final question] }\end{array}$ \\
\hline Q.2.14 & $\begin{array}{l}\text { Would you rather receive } 100 \text { Euro today or } 146 \\
\text { Euro in } 12 \text { months? }\end{array}$ & $\begin{array}{l}=\text { Today } \rightarrow \text { Go to question } 2.16 \\
=\text { In } 12 \text { months } \rightarrow \text { Go to } \\
\text { question } 2.15\end{array}$ \\
\hline Q.2.15 & $\begin{array}{l}\text { Would you rather receive } 100 \text { Euro today or } 143 \\
\text { Euro in } 12 \text { months? }\end{array}$ & $\begin{array}{l}=\text { Today [Final question] } \\
=\text { In } 12 \text { months [Final question] }\end{array}$ \\
\hline Q.2.16 & $\begin{array}{l}\text { Would you rather receive } 100 \text { Euro today or } 150 \\
\text { Euro in } 12 \text { months? }\end{array}$ & $\begin{array}{l}=\text { Today [Final question] } \\
=\text { In } 12 \text { months [Final question] }\end{array}$ \\
\hline Q.2.17 & $\begin{array}{l}\text { Would you rather receive } 100 \text { Euro today or } 185 \\
\text { Euro in } 12 \text { months? }\end{array}$ & $\begin{array}{l}=\text { Today } \rightarrow \text { Go to question } 2.18 \\
=\text { In } 12 \text { months } \rightarrow \text { Go to } \\
\text { question } 2.25\end{array}$ \\
\hline Q.2.18 & $\begin{array}{l}\text { Would you rather receive } 100 \text { Euro today or } 202 \\
\text { Euro in } 12 \text { months? }\end{array}$ & $\begin{array}{l}=\text { Today } \rightarrow \text { Go to question } 2.22 \\
=\text { In } 12 \text { months } \rightarrow \text { Go to } \\
\text { question } 2.19\end{array}$ \\
\hline Q.2.19 & $\begin{array}{l}\text { Would you rather receive } 100 \text { Euro today or } 193 \\
\text { Euro in } 12 \text { months? }\end{array}$ & $\begin{array}{l}=\text { Today } \rightarrow \text { Go to question } 2.20 \\
=\text { In } 12 \text { months } \rightarrow \text { Go to } \\
\text { question } 2.21\end{array}$ \\
\hline Q.2.20 & $\begin{array}{l}\text { Would you rather receive } 100 \text { Euro today or } 197 \\
\text { Euro in } 12 \text { months? }\end{array}$ & $\begin{array}{l}=\text { Today [Final question] } \\
=\text { In } 12 \text { months [Final question] }\end{array}$ \\
\hline Q.2.21 & $\begin{array}{l}\text { Would you rather receive } 100 \text { Euro today or } 189 \\
\text { Euro in } 12 \text { months? }\end{array}$ & $\begin{array}{l}=\text { Today }[\text { Final question }] \\
=\text { In } 12 \text { months [Final question] }\end{array}$ \\
\hline Q.2.22 & $\begin{array}{l}\text { Would you rather receive } 100 \text { Euro today or } 210 \\
\text { Euro in } 12 \text { months? }\end{array}$ & $\begin{array}{l}=\text { Today } \rightarrow \text { Go to question } 2.23 \\
=\text { In } 12 \text { months } \rightarrow \text { Go to }\end{array}$ \\
\hline
\end{tabular}




\begin{tabular}{|c|c|c|}
\hline & & question 2.24 \\
\hline Q.2.23 & $\begin{array}{l}\text { Would you rather receive } 100 \text { Euro today or } 215 \\
\text { Euro in } 12 \text { months? }\end{array}$ & $\begin{array}{l}=\text { Today [Final question] } \\
=\text { In } 12 \text { months [Final question] }\end{array}$ \\
\hline Q.2.24 & $\begin{array}{l}\text { Would you rather receive } 100 \text { Euro today or } 206 \\
\text { Euro in } 12 \text { months? }\end{array}$ & $\begin{array}{l}=\text { Today [Final question] } \\
=\text { In } 12 \text { months [Final question] }\end{array}$ \\
\hline Q.2.25 & $\begin{array}{l}\text { Would you rather receive } 100 \text { Euro today or } 169 \\
\text { Euro in } 12 \text { months? }\end{array}$ & $\begin{array}{l}=\text { Today } \rightarrow \text { Go to question } 2.29 \\
=\text { In } 12 \text { months } \rightarrow \text { Go to } \\
\text { question } 2.26\end{array}$ \\
\hline Q.2.26 & $\begin{array}{l}\text { Would you rather receive } 100 \text { Euro today or } 161 \\
\text { Euro in } 12 \text { months? }\end{array}$ & $\begin{array}{l}=\text { Today } \rightarrow \text { Go to question } 2.28 \\
=\text { In } 12 \text { months } \rightarrow \text { Go to } \\
\text { question } 2.27\end{array}$ \\
\hline Q.2.27 & $\begin{array}{l}\text { Would you rather receive } 100 \text { Euro today or } 158 \\
\text { Euro in } 12 \text { months? }\end{array}$ & $\begin{array}{l}=\text { Today [Final question] } \\
=\text { In } 12 \text { months [Final question] }\end{array}$ \\
\hline Q.2.28 & $\begin{array}{l}\text { Would you rather receive } 100 \text { Euro today or } 165 \\
\text { Euro in } 12 \text { months? }\end{array}$ & $\begin{array}{l}=\text { Today [Final question] } \\
=\text { In } 12 \text { months [Final question] }\end{array}$ \\
\hline Q.2.29 & $\begin{array}{l}\text { Would you rather receive } 100 \text { Euro today or } 177 \\
\text { Euro in } 12 \text { months? }\end{array}$ & $\begin{array}{l}=\text { Today } \rightarrow \text { Go to question } 2.31 \\
=\text { In } 12 \text { months } \rightarrow \text { Go to } \\
\text { question } 7.30\end{array}$ \\
\hline Q.2.30 & $\begin{array}{l}\text { Would you rather receive } 100 \text { Euro today or } 173 \\
\text { Euro in } 12 \text { months? }\end{array}$ & $\begin{array}{l}=\text { Today [Final question] } \\
=\text { In } 12 \text { months [Final question] }\end{array}$ \\
\hline Q.2.31 & $\begin{array}{l}\text { Would you rather receive } 100 \text { Euro today or } 181 \\
\text { Euro in } 12 \text { months? }\end{array}$ & $\begin{array}{l}=\text { Today [Final question] } \\
=\text { In } 12 \text { months [Final question] }\end{array}$ \\
\hline
\end{tabular}


Figure A5. Staircase method for time discounting. Tree for the staircase time task (numbers = payment in 12 months, A = choice of " $100 €$ today", B = choice of "x€ in 12 months"). This figure is reproduced from Falk et al., 2016.

Notes. The staircase procedure worked as follows. First, each respondent was asked whether they would prefer to receive $100 €$ today or $154 €$ in 12 months from now (leftmost decision node). In case the respondent opted for the payment today (" $A$ "), in the second question the payment in 12 months was adjusted upwards to $185 €$. If, on the other hand, the respondent chose the payment in 12 months, the corresponding payment was adjusted down to 125€. Working further through the tree follows the same logic. 


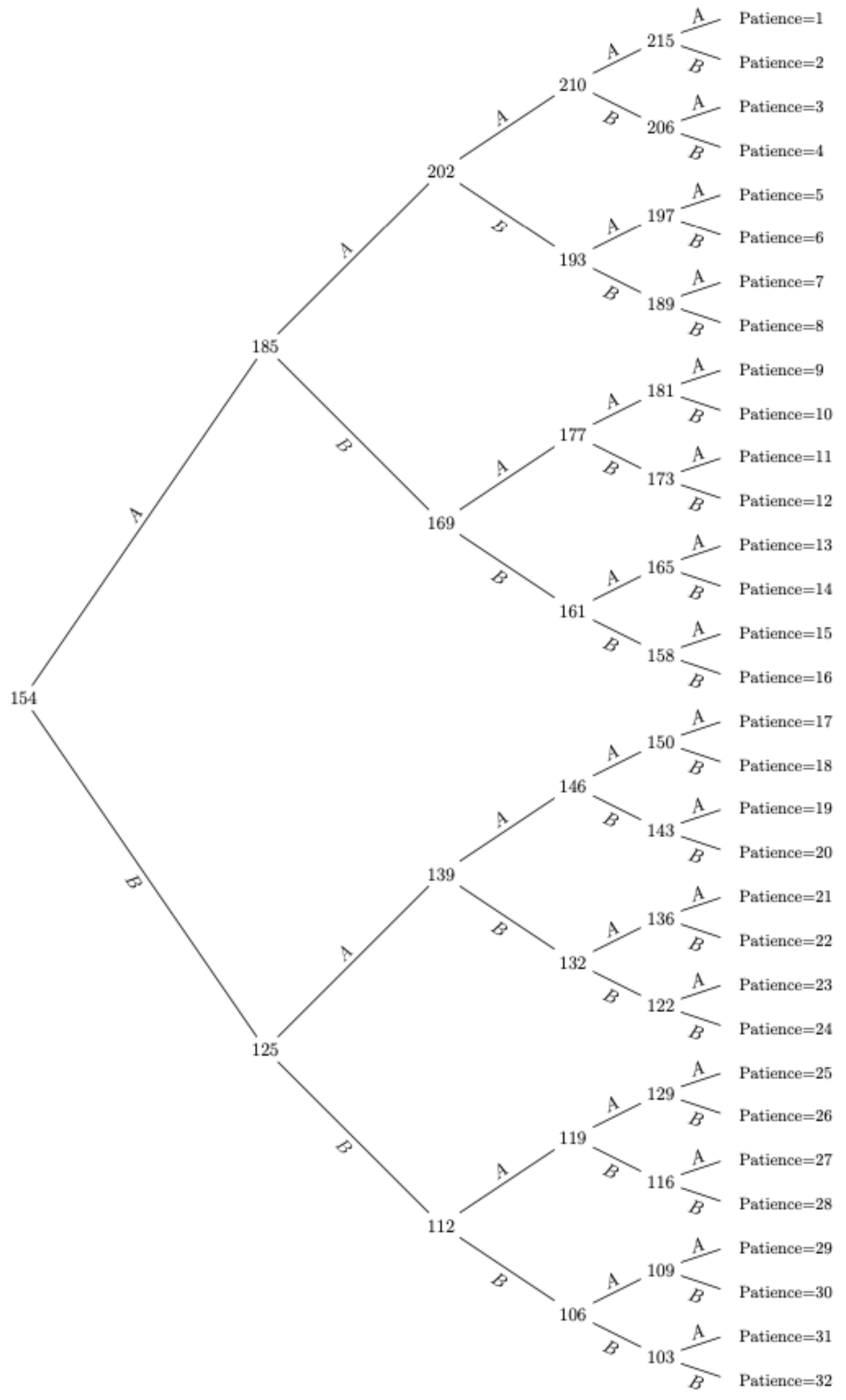


Table A8. Measure of risk aversion. Each participant was asked to answer a series of five questions from a list of 31 hypothetical choices between a lottery (300€ with a 50-percent chance and $0 €$ with a 50 -percent chance) and varying safe options (starting at $0 €$ and increasing to $300 €$ in increments of $10 €)$. To determine the alternatives given to an individual, we implemented a "staircase" procedure. Depending on the individual's answer (the sure payment or the lottery), she was a higher or lower safe option in order to find the smallest safe amount for which the participant preferred the safe amount to the lottery.

\begin{tabular}{|c|c|c|}
\hline Number & Question & Answer and next question \\
\hline Q.1.1 & $\begin{array}{l}\text { What would you prefer: a draw with a } 50 \text { percent } \\
\text { chance of receiving } 300 \text { Euro, and the same } 50 \\
\text { percent chance of receiving nothing, or the } \\
\text { amount of } 160 \text { Euro as a sure payment? }\end{array}$ & $\begin{array}{l}=50 / 50 \text { chance } \rightarrow \text { Go to } \\
\text { question } 1.17 \\
=\text { Sure payment } \rightarrow \text { Go to } \\
\text { question } 1.2\end{array}$ \\
\hline Q.1.2 & $\begin{array}{l}\text { Would you prefer the } 50 / 50 \text { chance or the } \\
\text { amount of } 80 \text { Euro as a sure payment? }\end{array}$ & $\begin{array}{l}=50 / 50 \text { chance } \rightarrow \text { Go to } \\
\text { question } 1.10 \\
=\text { Sure payment } \rightarrow \text { Go to } \\
\text { question } 1.3\end{array}$ \\
\hline Q.1.3 & $\begin{array}{l}\text { Would you prefer the } 50 / 50 \text { chance or the } \\
\text { amount of } 40 \text { Euro as a sure payment? }\end{array}$ & $\begin{array}{l}=50 / 50 \text { chance } \rightarrow \text { Go to } \\
\text { question } 1.4 \\
=\text { Sure payment } \rightarrow \text { Go to } \\
\text { question } 1.7\end{array}$ \\
\hline Q.1.4 & $\begin{array}{l}\text { Would you prefer the } 50 / 50 \text { chance or the } \\
\text { amount of } 60 \text { Euro as a sure payment? }\end{array}$ & $\begin{array}{l}=50 / 50 \text { chance } \rightarrow \text { Go to } \\
\text { question } 1.5 \\
=\text { Sure payment } \rightarrow \text { Go to } \\
\text { question } 1.6\end{array}$ \\
\hline Q.1.5 & $\begin{array}{l}\text { Would you prefer the } 50 / 50 \text { chance or the } \\
\text { amount of } 70 \text { Euro as a sure payment? }\end{array}$ & $\begin{array}{l}=50 / 50 \text { chance } \rightarrow \text { Go to next } \\
\text { section } \\
=\text { Sure payment } \rightarrow \text { Go to next } \\
\text { section }\end{array}$ \\
\hline Q.1.6 & $\begin{array}{l}\text { Would you prefer the } 50 / 50 \text { chance or the } \\
\text { amount of } 50 \text { Euro as a sure payment? }\end{array}$ & $\begin{array}{l}=50 / 50 \text { chance } \rightarrow \text { Go to next } \\
\text { section } \\
=\text { Sure payment } \rightarrow \text { Go to next } \\
\text { section }\end{array}$ \\
\hline
\end{tabular}




\begin{tabular}{|c|c|c|}
\hline Q.1.7 & $\begin{array}{l}\text { Would you prefer the } 50 / 50 \text { chance or the } \\
\text { amount of } 20 \text { Euro as a sure payment? }\end{array}$ & $\begin{array}{l}=50 / 50 \text { chance } \rightarrow \text { Go to } \\
\text { question } 1.8 \\
=\text { Sure payment } \rightarrow \text { Go to } \\
\text { question } 1.9\end{array}$ \\
\hline Q.1.8 & $\begin{array}{l}\text { Would you prefer the } 50 / 50 \text { chance or the } \\
\text { amount of } 30 \text { Euro as a sure payment? }\end{array}$ & $\begin{array}{l}=50 / 50 \text { chance } \rightarrow \text { Go to next } \\
\text { section } \\
=\text { Sure payment } \rightarrow \text { Go to next } \\
\text { section }\end{array}$ \\
\hline Q.1.9 & $\begin{array}{l}\text { Would you prefer the } 50 / 50 \text { chance or the } \\
\text { amount of } 10 \text { Euro as a sure payment? }\end{array}$ & $\begin{array}{l}=50 / 50 \text { chance } \rightarrow \text { Go to next } \\
\text { section } \\
=\text { Sure payment } \rightarrow \text { Go to next } \\
\text { section }\end{array}$ \\
\hline Q.1.10 & $\begin{array}{l}\text { Would you prefer the } 50 / 50 \text { chance or the } \\
\text { amount of } 120 \text { Euro as a sure payment? }\end{array}$ & $\begin{array}{l}=50 / 50 \text { chance } \rightarrow \text { Go to } \\
\text { question } 1.14 \\
=\text { Sure payment } \rightarrow \text { Go to } \\
\text { question } 1.11\end{array}$ \\
\hline Q.1.11 & $\begin{array}{l}\text { Would you prefer the } 50 / 50 \text { chance or the } \\
\text { amount of } 100 \text { Euro as a sure payment? }\end{array}$ & $\begin{array}{l}=50 / 50 \text { chance } \rightarrow \text { Go to } \\
\text { question } 1.13 \\
=\text { Sure payment } \rightarrow \text { Go to } \\
\text { question } 1.12\end{array}$ \\
\hline Q.1.12 & $\begin{array}{l}\text { Would you prefer the } 50 / 50 \text { chance or the } \\
\text { amount of } 90 \text { Euro as a sure payment? }\end{array}$ & $\begin{array}{l}=50 / 50 \text { chance } \rightarrow \text { Go to next } \\
\text { section } \\
=\text { Sure payment } \rightarrow \text { Go to next } \\
\text { section }\end{array}$ \\
\hline Q.1.13 & $\begin{array}{l}\text { Would you prefer the } 50 / 50 \text { chance or the } \\
\text { amount of } 110 \text { Euro as a sure payment? }\end{array}$ & $\begin{array}{l}=50 / 50 \text { chance } \rightarrow \text { Go to next } \\
\text { section } \\
=\text { Sure payment } \rightarrow \text { Go to next } \\
\text { section }\end{array}$ \\
\hline Q.1.14 & $\begin{array}{l}\text { Would you prefer the } 50 / 50 \text { chance or the } \\
\text { amount of } 140 \text { Euro as a sure payment? }\end{array}$ & $\begin{array}{l}=50 / 50 \text { chance } \rightarrow \text { Go to } \\
\text { question } 1.15 \\
=\text { Sure payment } \rightarrow \text { Go to } \\
\text { question } 1.16\end{array}$ \\
\hline Q.1.15 & Would you prefer the $50 / 50$ chance or the & $=50 / 50$ chance $\rightarrow$ Go to next \\
\hline
\end{tabular}




\begin{tabular}{|l|l|l|}
\hline amount of 150 Euro as a sure payment? & $\begin{array}{l}\text { section } \\
=\text { Sure payment } \rightarrow \text { Go to next } \\
\text { section }\end{array}$ \\
\hline Q.1.16 & $\begin{array}{l}\text { Would you prefer the } 50 / 50 \text { chance or the } \\
\text { amount of } 130 \text { Euro as a sure payment? }\end{array}$ & $\begin{array}{l}=50 / 50 \text { chance } \rightarrow \text { Go to next } \\
\text { section } \\
=\text { Sure payment } \rightarrow \text { Go to next } \\
\text { section }\end{array}$ \\
\hline Q.1.17 & $\begin{array}{l}\text { Would you prefer the } 50 / 50 \text { chance or the } \\
\text { amount of } 240 \text { Euro as a sure payment? }\end{array}$ & $\begin{array}{l}=50 / 50 \text { chance } \rightarrow \text { Go to } \\
\text { question } 1.25 \\
=\text { Sure payment } \rightarrow \text { Go to } \\
\text { question } 1.18\end{array}$ \\
\hline Q.1.18 & $\begin{array}{l}\text { Would you prefer the } 50 / 50 \text { chance or the } \\
\text { amount of } 200 \text { Euro as a sure payment? }\end{array}$ & $\begin{array}{l}=50 / 50 \text { chance } \rightarrow \text { Go to } \\
\text { question } 1.22 \\
=\text { Sure payment } \rightarrow \text { Go to } \\
\text { question } 1.19\end{array}$ \\
\hline Q.1.1.21 & $\begin{array}{l}\text { Would you prefer the } 50 / 50 \text { chance or the } \\
\text { amount of } 180 \text { Euro as a sure payment? }\end{array}$ & $\begin{array}{l}\text { Would you prefer the } 50 / 50 \text { chance or the } \\
\text { amount of } 170 \text { Euro as a sure payment? } \\
\text { question } 1.20 \\
=\text { Sure payment } \rightarrow \text { Go to } \\
\text { question } 1.21\end{array}$ \\
\hline amount of 230 Euro as a sure payment?
\end{tabular}




\begin{tabular}{|c|c|c|}
\hline & & $\begin{array}{l}=\text { Sure payment } \rightarrow \text { Go to next } \\
\text { section }\end{array}$ \\
\hline Q.1.24 & $\begin{array}{l}\text { Would you prefer the } 50 / 50 \text { chance or the } \\
\text { amount of } 210 \text { Euro as a sure payment? }\end{array}$ & $\begin{array}{l}=50 / 50 \text { chance } \rightarrow \text { Go to next } \\
\text { section } \\
=\text { Sure payment } \rightarrow \text { Go to next } \\
\text { section }\end{array}$ \\
\hline Q.1.25 & $\begin{array}{l}\text { Would you prefer the } 50 / 50 \text { chance or the } \\
\text { amount of } 280 \text { Euro as a sure payment? }\end{array}$ & $\begin{array}{l}=50 / 50 \text { chance } \rightarrow \text { Go to } \\
\text { question } 1.29 \\
=\text { Sure payment } \rightarrow \text { Go to } \\
\text { question } 1.26\end{array}$ \\
\hline Q.1.26 & $\begin{array}{l}\text { Would you prefer the } 50 / 50 \text { chance or the } \\
\text { amount of } 260 \text { Euro as a sure payment? }\end{array}$ & $\begin{array}{l}=50 / 50 \text { chance } \rightarrow \text { Go to } \\
\text { question } 1.27 \\
=\text { Sure payment } \rightarrow \text { Go to } \\
\text { question } 1.28\end{array}$ \\
\hline Q.1.27 & $\begin{array}{l}\text { Would you prefer the } 50 / 50 \text { chance or the } \\
\text { amount of } 270 \text { Euro as a sure payment? }\end{array}$ & $\begin{array}{l}=50 / 50 \text { chance } \rightarrow \text { Go to next } \\
\text { section } \\
=\text { Sure payment } \rightarrow \text { Go to next } \\
\text { section }\end{array}$ \\
\hline Q.1.28 & $\begin{array}{l}\text { Would you prefer the } 50 / 50 \text { chance or the } \\
\text { amount of } 250 \text { Euro as a sure payment? }\end{array}$ & $\begin{array}{l}=50 / 50 \text { chance } \rightarrow \text { Go to next } \\
\text { section } \\
=\text { Sure payment } \rightarrow \text { Go to next } \\
\text { section }\end{array}$ \\
\hline Q.1.29 & $\begin{array}{l}\text { Would you prefer the } 50 / 50 \text { chance or the } \\
\text { amount of } 300 \text { Euro as a sure payment? }\end{array}$ & $\begin{array}{l}=50 / 50 \text { chance } \rightarrow \text { Go to } \\
\text { question } 1.31 \\
=\text { Sure payment } \rightarrow \text { Go to } \\
\text { question } 1.30\end{array}$ \\
\hline Q.1.30 & $\begin{array}{l}\text { Would you prefer the } 50 / 50 \text { chance or the } \\
\text { amount of } 290 \text { Euro as a sure payment? }\end{array}$ & $\begin{array}{l}=50 / 50 \text { chance } \rightarrow \text { Go to next } \\
\text { section } \\
=\text { Sure payment } \rightarrow \text { Go to next } \\
\text { section }\end{array}$ \\
\hline Q.1.31 & $\begin{array}{l}\text { Would you prefer the } 50 / 50 \text { chance or the } \\
\text { amount of } 310 \text { Euro as a sure payment? }\end{array}$ & $\begin{array}{l}=50 / 50 \text { chance } \rightarrow \text { Go to next } \\
\text { section } \\
=\text { Sure payment } \rightarrow \text { Go to next }\end{array}$ \\
\hline
\end{tabular}


COVID-19 and risk and time preferences

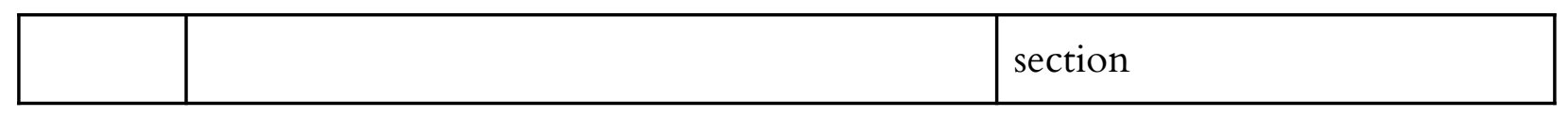


Figure A6. Staircase method for risk aversion. Tree for the staircase risk task (numbers $=$ sure payment, $\mathrm{A}=$ choice of sure payment, $\mathrm{B}=$ choice of lottery). This figure is reproduced from Falk et al., 2016.

Notes. The staircase procedure worked as follows. First, each respondent was asked whether they would prefer to receive $160 €$ for sure or whether they preferred a 50:50 chance of receiving $300 €$ or nothing. In case the respondent opted for the safe choice (" $B$ "), the safe amount of money being offered in the second question decreased to $80 €$. If, on the other hand, the respondent opted for the gamble ("A"), the safe amount was increased to $240 €$. Working further through the tree follows the same logic. 


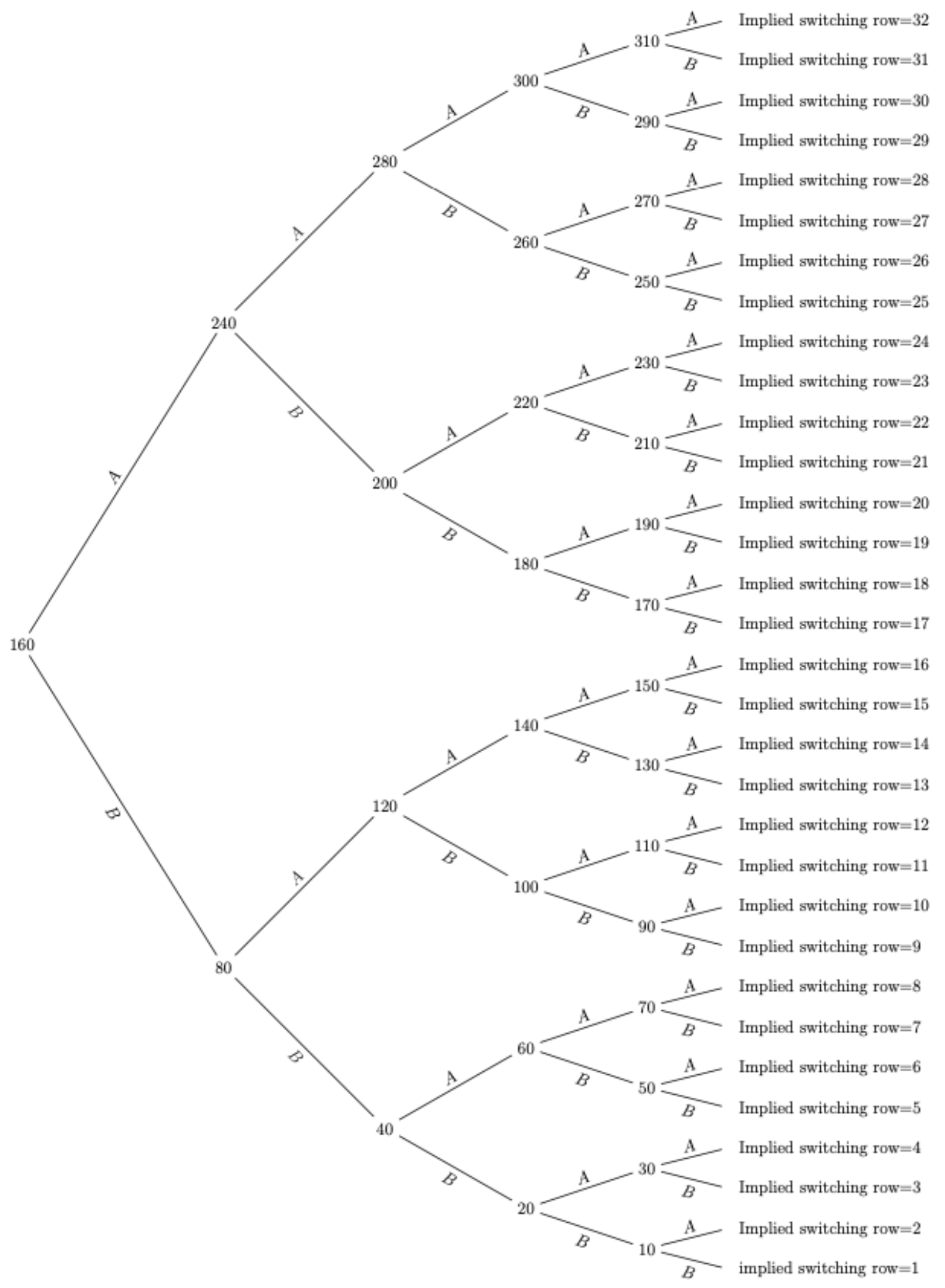

